PRACE GEOGRAFICZNE

zeszyt $155,2018,7-26$

doi: 10.4467/20833113PG.18.013.9536

Instytut Geografii i Gospodarki Przestrzennej UJ

Wydawnictwo Uniwersytetu Jagiellońskiego

\title{
WIELOLETNIA I SEZONOWA ZMIENNOŚĆ WYDAJNOŚCI ŹRÓDEŁ SUDETÓW I KARPAT
}

\author{
Adam Bartnik, Piotr Moniewski
}

\section{Multiannual and seasonal diversity of spring discharge in the Sudetes and Carpathians}

\begin{abstract}
Discharge is one of the most important quantitative characteristics of springs. Not only does it specify the yield of groundwater, but it also reflects the water retention conditions of the aquifers. An analysis of the long-term spring discharge allows to link them to the hydrogeological and meteorological conditions of the area as well as to calculate the seasonal and multiannual variability parameters. The data from 84 springs in the south of Poland from the PIG-PIB databases were used in the paper. The time series differ in length and come from the period 1973-2016. The spring discharge variability index varies widely: from 2 to over 2 thousand, wherein the contribution of slightly variable, variable and highly variable springs is around 33\%. The discharge of individual springs featured significant seasonal variations. Not only does the volume of outflowing water depend on the atmospheric conditions, but primarily on the properties of aquifer which feeds the spring's groundwater catchment and on its location. The discharge of fissure springs as well as low-flow outflows is generally more variable than that of porous or karst springs. The seasonality of discharge depends less on the discharge of the spring and more on its elevation - springs which are at higher altitudes are characterized by a bigger seasonality index of discharge and a later date of its yearly peak discharge.
\end{abstract}

Keywords: springs, Sudetes, Carpathians, discharge of springs, variability of discharge, groundwater

Zarys treści: Wydajność jest jedną z najważniejszych charakterystyk ilościowych źródeł. Determinuje ona nie tylko rozmiary wypływów wód podziemnych, ale odzwierciedla również stan 
retencji ich wodonośca. Analiza wydajności źródeł w dłuższej perspektywie czasowej umożliwia jej powiązanie z warunkami hydrogeologicznymi i meteorologicznymi obszaru zasilania oraz obliczenie charakterystyk zmienności sezonowej i wieloletniej. W pracy wykorzystano, pochodzące z baz danych PIG-PIB, dane o wydajności 84 źródeł znajdujących się w południowej Polsce. Serie pomiarowe mają różną długość i pochodzą z lat 1973-2016. Współczynnik zmienności Mailleta wydajności źródeł zmieniał się w szerokim zakresie: od 2 do ponad 2 tysięcy, przy czym udział wypływów mało zmiennych, zmiennych i bardzo zmiennych stanowi po około 33\%. Wydajność poszczególnych źródeł cechuje znaczne zróżnicowanie sezonowe. Ilość wypływającej wody zależy nie tylko od warunków zasilania atmosferycznego, lecz przede wszystkim od hydrogeologicznych właściwości zlewni podziemnej wypływu i jego położenia. Źródła szczelinowe, a także wypływy o niewielkiej wydajności odznaczają się na ogół znacznie większą zmiennością wydatku niż wypływy porowe lub krasowe. Natomiast sezonowość wydajności w mniejszym stopniu zależy od wielkości wypływu, w większym zaś od jego wysokości - źródła położone na większej wysokości bezwzględnej charakteryzują się wyższym indeksem sezonowości wydajności i późniejszą porą jej koncentracji.

Stowa kluczowe: źródła, Sudety, Karpaty, wydajność źródeł, zmienność wydajności, wody podziemne

\section{Wstęp}

Wydajność źródła jest funkcją szeregu czynników, głównie meteorologicznych i hydrogeologicznych, które możemy zobrazować poprzez ocenę wielkości zasilania, parametry zlewni podziemnej i jej lokalizację w przestrzeni. Współczesna krenologia dysponuje bogatym aparatem metod badawczych, pozwalających na poznanie ilościowych parametrów wypływów wód podziemnych. Geologiczne cechy wodonośca są praktycznie stałe, lecz siła oddziaływania pozostałych czynników zmienia się z upływem czasu (Chełmicki i in. 2011). Dynamika wypływu jest zwykle zależna od warunków meteorologicznych determinujących wielkość zasilania zlewni podziemnej, a wraz z budującymi ją skałami - kształtujących cechy fizykochemiczne wód podziemnych (temperaturę, odczyn, przewodność itp.). Wpływają one przede wszystkim na zdolność infiltracji, a więc na ilość wody przenikającej do skorupy ziemskiej. Ponadto, stan retencji wodonośca reguluje ciśnienie hydrostatyczne warstwy wodonośnej, które wraz z jej temperaturą determinują tempo przemieszczania się wody w jego wnętrzu. Objętość wody wypływająca ze źródła jest zatem konsekwencją procesów zachodzących w jego podziemnej zlewni. Jej analiza w dłuższej perspektywie czasowej umożliwia wyodrębnienie tych czynników obszaru zasilania, które mają największy wpływ na transformację opadu. Pozwala także na obliczenie charakterystyk sezonowej i wieloletniej zmienności wydajności wypływów.

Badaniom źródeł Polski poświęcono wiele opracowań naukowych, z których znaczna część dotyczy polskich wyżyn. Problematyką wydajności wybranych wypływów tego obszaru zajmowali się m. in.: Czarnecka (1975), Michalczyk (1982, 
1983, 1993), Michalczyk i Rederowa (1992) oraz Siwek (2013). Dotychczas niewielu badaczy podjęło się analiz zmian wydajności źródeł wymagających porównania pojedynczych pomiarów wykonywanych w dłuższych odstępach czasu (Chełmicki 2001; Siwek 2013; Michalczyk i in. 2015) bądź wieloletnich szeregów ich wydajności (Michalczyk, Turczyński 1999; Michalczyk i in. 2009; Michalczyk, Chabudziński 2013).

W porównaniu z wyżynami znacznie słabiej przebadane pod względem krenologicznym są nizinne obszary naszego kraju. Należy jednak zauważyć, że w ostatnich latach nastąpił wyraźny wzrost zainteresowania źródłami tego terenu w poszczególnych ośrodkach naukowych (Nowakowski 1976; Jekatierynczuk-Rudczyk 2005; Fac-Beneda 2009; Mazurek 2010; Cieśliński, Leśniowski 2013; Florek i in. 2014; Górniak, Pietryczuk 2015; Pius i in. 2016). Jednakże analizy oparte na regularnych pomiarach wydajności wypływów wód podziemnych nadal pojawiają się sporadycznie (Moniewski 2004; Puk 2005; Szczucińska 2009; Jaworska-Szulc i in. 2015).

W podobny sposób można oceniać tematykę prac krenologicznych z obszarów górskich południowej Polski. Wśród licznych opracowań dotyczących źródeł Sudetów i Karpat znaczną część poświęcono ich rozmieszczeniu i cechom fizykochemicznym wody. Traktują o tym m.in. prace: Bartnika (2007), Wolanin i Żelaznego (2010), Buczyńskiego i in. (2011, 2017), Buczyńskiego i Rzoncy (2013). Rzadziej badano wieloletnie zmiany wydajności wypływów, choć prac na ten temat ukazuje się w ostatnich latach coraz więcej (Jokiel 1994, 1996, 1997; Małecka 1997; Humnicki 2006, 2012, 2015; Barczyk 2008; Satora i in. 2010; Moniewski 2015, 2016). Opracowania te skupiają się jednak najczęściej na kilku obiektach zlokalizowanych w obrębie wybranego mezoregionu. Dlatego autorzy niniejszej publikacji, wykorzystując dostępność danych, podjęli próbę zbadania zmienności wydajności większej grupy źródeł z obszaru Sudetów i Karpat.

\section{Dane i metody opracowania}

W pracy wykorzystano dane z udostępnionych przez Państwowy Instytut Geologiczny (PIG-PIB) baz danych hydrogeologicznych: Centralnego Banku Danych Hydrogeologicznych - Banku HYDRO (CBDH) oraz bazy Monitoringu Wód Podziemnych (MWP). Łącznie, zawierają one informacje dotyczące 87 wypływów. Serie pomiarowe mają różną długość i pochodzą z lat 1973-2016.

Analizom poddano wydajność 84 wypływów znajdujących się na obszarze górskim i pogórskim południowej Polski (tab. 1). Większość badanych źródeł (68\%) położona jest w Karpatach i na Podkarpaciu, pozostałe (32\%) leżą w Sudetach i na ich przedgórzu (ryc. 1). Spośród mezoregionów południowej Polski najliczniej reprezentowane są Beskidy Zachodnie (21 wypływów), Sudety Środkowe (17) oraz 


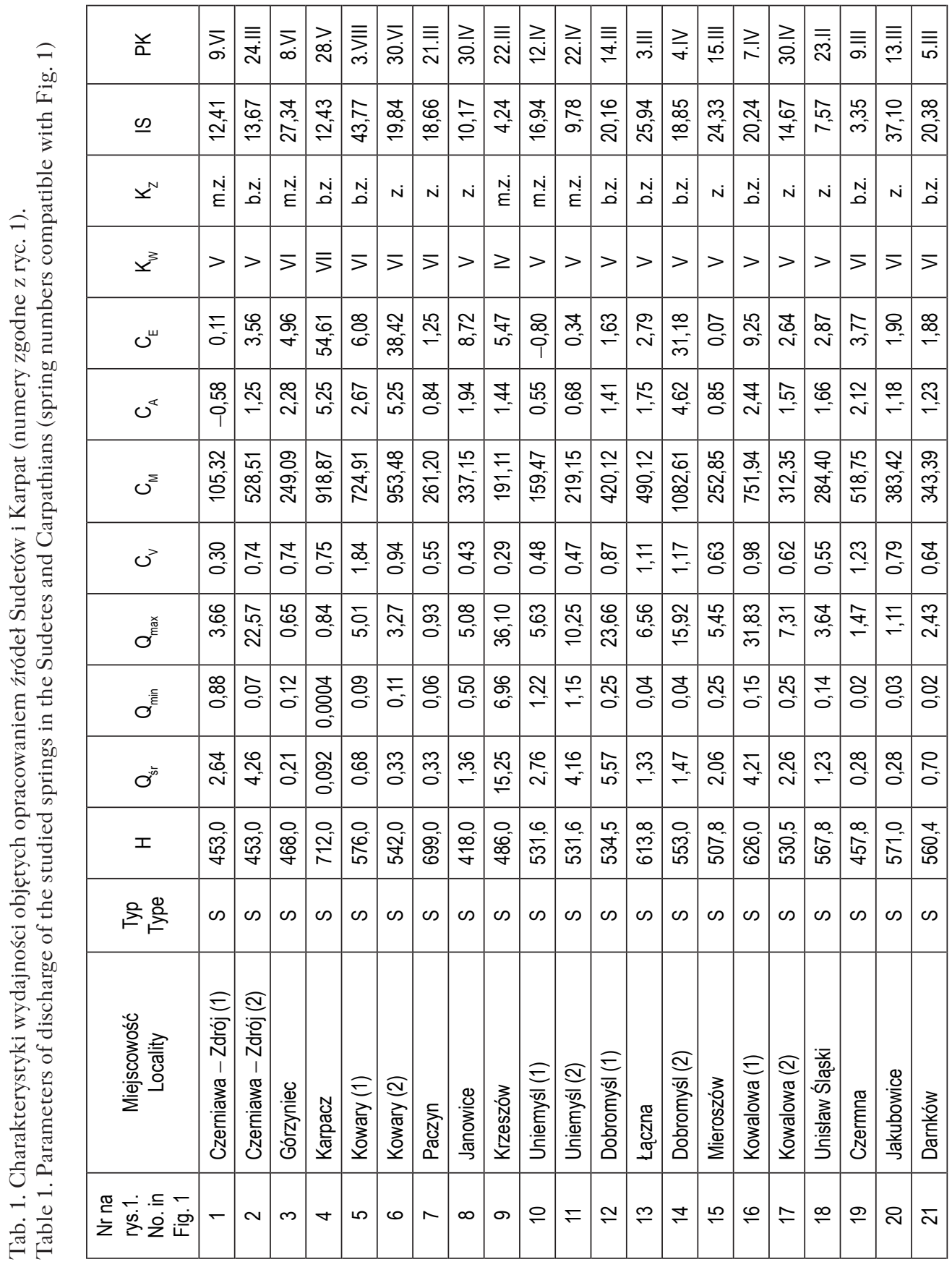




\begin{tabular}{|c|c|c|c|c|c|c|c|c|c|c|c|c|c|c|c|c|c|c|c|c|c|c|c|c|}
\hline 产 & $\underset{\forall}{\gtrless}$ & 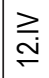 & 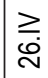 & $\underset{N}{\geqq}$ & $\equiv$ & $\equiv$ & $\begin{array}{l}\bar{x} \\
\stackrel{m}{p}\end{array}$ & $\underset{\dot{m}}{\stackrel{2}{m}}$ & $\underset{\omega}{\gtrless}$ & $\underset{\bar{m}}{\bar{j}}$ & $\underset{6}{\gtrless}$ & $\equiv$ & \begin{tabular}{|l|}
$\overline{0}$ \\
$\dot{\sim}$
\end{tabular} & $\vec{i}$ & $\geqq$ & $\begin{array}{l}\Sigma \\
0 \\
\end{array}$ & $\underset{\sim}{\grave{\sim}}$ & $\stackrel{\gtrless}{\rightleftarrows}$ & $\stackrel{\equiv}{\equiv}$ & $\stackrel{\bar{x}}{F}$ & $\underset{\sim}{\stackrel{d}{d}}$ & $\underset{\mathrm{i}}{\stackrel{\sum}{ }}$ & $\underset{\Sigma}{\equiv}$ & $\stackrel{i}{\sim}$ \\
\hline$\underline{\omega}$ & $\stackrel{\text { న్ }}{\leftarrow}$ & 은 & $\stackrel{\text { m }}{\stackrel{2}{*}}$ & $\stackrel{\text { N }}{F}$ & 茴 & 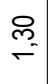 & $\begin{array}{l}0 \\
\text { en } \\
\text { గn }\end{array}$ & $\begin{array}{l}\infty \\
\infty \\
\infty \\
\infty\end{array}$ & कू & $\begin{array}{l}\infty \\
\infty \\
6 \\
6\end{array}$ & $\begin{array}{l}\text { O } \\
0 \\
0 \\
\text { ల }\end{array}$ & $\begin{array}{l}\tilde{m} \\
\text { N- }\end{array}$ & \begin{tabular}{|l|}
$\infty$ \\
$\infty$ \\
0 \\
0 \\
0
\end{tabular} & 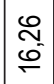 & 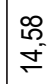 & $\begin{array}{l}N \\
m^{-1}\end{array}$ & $\mid \begin{array}{l}0 \\
\infty \\
0 \\
0\end{array}$ & \begin{tabular}{|l|}
$\mathbb{2}$ \\
in
\end{tabular} & $\begin{array}{l}\mathscr{8} \\
\stackrel{5}{L}\end{array}$ & 穴 & 㐫 & $\begin{array}{l}0 \\
0 \\
\mathbb{1}\end{array}$ & 疍 & $\stackrel{\infty}{\infty}$ \\
\hline$x^{N}$ & $\stackrel{N}{E}$ & $N$ & $N$ & $\stackrel{N}{E}$ & $\dot{\omega}$ & $\stackrel{N}{E}$ & $N$ & مِ & $N$ & مِ & $N$ & مِ & مُ & مِ & Nㅗㅇ & $\stackrel{\stackrel{N}{E}}{E}$ & $\stackrel{N}{E}$ & $\stackrel{N}{E}$ & فِ & $\stackrel{N}{E}$ & $\stackrel{\stackrel{N}{E}}{E}$ & $N$ & $N$ & $N$ \\
\hline$x^{3}$ & $\geq$ & $>$ & $>$ & $>$ & $>$ & $>$ & $>$ & $>$ & $>$ & $>$ & $>$ & $>$ & $>$ & $>$ & $>$ & $>$ & $\equiv$ & $\bar{\xi}$ & $>$ & $\equiv$ & $>$ & $>$ & $>$ & $>$ \\
\hline ن" & ্ָd & O্ & $\stackrel{\cong}{m}$ & $\begin{array}{l}L \\
\stackrel{2}{\Omega} \\
\end{array}$ & $\stackrel{m}{\sim}$ & 8 & $\begin{array}{l}n \\
0 \\
0 \\
0\end{array}$ & 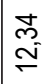 & $\begin{array}{l}0 \\
0 \\
0 \\
0\end{array}$ & $\begin{array}{l}\frac{0}{6} \\
6\end{array}$ & $\begin{array}{l}\text { s. } \\
\text { o }\end{array}$ & న్ & $\begin{array}{l}8 \\
0 \\
6\end{array}$ & $\begin{array}{l}\bar{m} \\
\tilde{m}^{-}\end{array}$ & $\begin{array}{l}\otimes \\
\ddot{m}\end{array}$ & 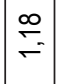 & $\begin{array}{l}\hat{A} \\
0\end{array}$ & 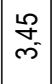 & $\begin{array}{l}8 \\
0 \\
0 \\
1\end{array}$ & \begin{tabular}{ll}
$\mathscr{B}$ \\
\hdashline \\
0
\end{tabular} & $\begin{array}{l}\mathscr{8} \\
\\
0\end{array}$ & Ë & $\underset{N}{N}$ & $\begin{array}{l}\infty \\
0 \\
0\end{array}$ \\
\hline $0^{\pi}$ & $\begin{array}{l}\text { ¿ } \\
\text { is }\end{array}$ & $\underset{N}{\mathbb{N}}$ & $\stackrel{2}{\stackrel{2}{=}}$ & $\stackrel{\mathscr{Q}}{=}$ & $\underset{\sim}{\stackrel{J}{*}}$ & $\ddot{0}$ & g. & 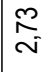 & న్ & $\stackrel{\circ}{\sim}$ & 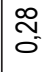 & $\stackrel{?}{=}$ & $\begin{array}{l}\hat{0} \\
\mathrm{i}\end{array}$ & $\stackrel{\mathscr{R}}{\leftarrow}$ & $\bar{m}$ & $\begin{array}{c}0 \\
0 \\
0\end{array}$ & $\begin{array}{l}\mathscr{8} \\
\mathbb{O} \\
0\end{array}$ & 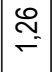 & L & \begin{tabular}{|l|}
2 \\
0 \\
\\
1
\end{tabular} & $\stackrel{8}{-}$ & $\underset{0}{0}$ & $\underset{\sigma}{\check{\sigma}}$ & 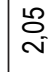 \\
\hline $0^{\Sigma}$ & $\frac{\pi}{N}$ & $\begin{array}{l}\hat{\omega} \\
\tilde{0} \\
\tilde{\omega}\end{array}$ & $\begin{array}{l}\text { \% } \\
\text { o } \\
\text { O }\end{array}$ & 芯 & 苂 & $\begin{array}{l}\infty \\
\stackrel{\infty}{\Gamma}\end{array}$ & $\begin{array}{l}\overline{6} \\
\text { స్ }\end{array}$ & $\begin{array}{l}\text { J } \\
\text { \& } \\
0\end{array}$ & 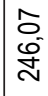 & : & 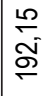 & 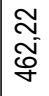 & $\begin{array}{l}0 \\
0 \\
8 \\
8 \\
\end{array}$ & $\begin{array}{l}\mathscr{8} \\
8 \\
8 \\
\\
\end{array}$ & 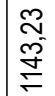 & 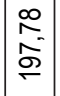 & 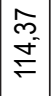 & 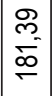 & $\begin{array}{l}\stackrel{P}{+} \\
\infty \\
\stackrel{0}{\sim}\end{array}$ & $\mid \begin{array}{l}0 \\
9 \\
\sigma \\
\rightleftharpoons \\
\end{array}$ & $\begin{array}{l}8 \\
8 \\
0 \\
0 \\
0\end{array}$ & 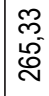 & 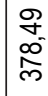 & $\begin{array}{l}\infty \\
\infty \\
\infty \\
\infty \\
\text { mे }\end{array}$ \\
\hline 0 & $\frac{\infty}{0}$ & 梂 & $\begin{array}{l}\Omega \\
0 \\
0\end{array}$ & 웅 & $E_{0}$ & $\frac{\varrho}{0}$ & ळ & $\begin{array}{l}1 \\
\infty \\
0 \\
0\end{array}$ & ઉ̃ & 瞒 & 8 & $\underset{-}{\sigma}$ & \begin{tabular}{|l|} 
\\
$\infty$ \\
$\infty$ \\
0
\end{tabular} & $\mid \begin{array}{l}\mathscr{D} \\
0_{0} \\
0^{\prime}\end{array}$ & $\stackrel{0}{\circ}$ & $\begin{array}{l}\tilde{m} \\
\tilde{0}\end{array}$ & 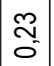 & $\begin{array}{l}\mathbb{2} \\
\mathbb{N} \\
0\end{array}$ & 8 & \begin{tabular}{|l|} 
\\
ల్ \\
0
\end{tabular} & 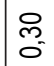 & $\begin{array}{l}8 \\
10 \\
0\end{array}$ & 它 & $\mid \begin{array}{l}\infty \\
10 \\
0 \\
0\end{array}$ \\
\hline $0^{\frac{x}{E}}$ & $\begin{array}{l}8 \\
\stackrel{0}{2}\end{array}$ & $\bar{\sigma}$ & $\stackrel{N}{\stackrel{N}{-}}$ & م & $\overline{\hat{\sigma}}$ & $\stackrel{m}{\sim}$ & $\bar{\sigma}_{0}$ & 艿 & \begin{tabular}{|l}
$\frac{2}{2}$ \\
0
\end{tabular} & $\stackrel{\text { N }}{\sim}$ & $\stackrel{\mathbb{2}}{\stackrel{2}{-}}$ & $\stackrel{0}{i}$ & $\begin{array}{l}\tilde{j} \\
\sim \\
\sim\end{array}$ & $\begin{array}{l}\bar{\infty} \\
\sigma_{0}\end{array}$ & $\stackrel{\stackrel{L}{\circ}}{\sim}$ & $\mid \begin{array}{l}\infty \\
\ddot{\delta} \\
0\end{array}$ & $\stackrel{\simeq}{\check{0}}$ & $\frac{10}{5}$ & 8 & \begin{tabular}{|l|}
$\infty$ \\
0 \\
j్
\end{tabular} & f & 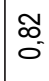 & $\begin{array}{l}10 \\
0 \\
0\end{array}$ & $\begin{array}{l}\frac{2}{2} \\
0 \\
0\end{array}$ \\
\hline$\sigma^{\frac{c}{E}}$ & $\begin{array}{l}\hat{\omega} \\
\omega \\
\omega\end{array}$ & 柋 & $\stackrel{\simeq}{0}$ & శ్ & 守 & 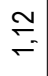 & O̊. & O̊. & $\widetilde{\sigma}$ & Ö & g. & 足 & $\bar{\delta}$ & $\bar{\delta}$ & $\bar{\delta}$ & 응 & 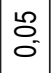 & $\begin{array}{l}0 \\
0 \\
0 \\
0\end{array}$ & $\bar{\delta}_{0}$ & $\mid \begin{array}{c}\Omega \\
\infty \\
0 \\
\sigma \\
\sigma\end{array}$ & 8. & $\widetilde{O}$ & $\frac{12}{5}$ & $\tilde{O}$ \\
\hline $0^{i \bar{m}}$ & $\begin{array}{l}8 \\
0 \\
0\end{array}$ & $\stackrel{\mathbb{N}}{=}$ & 舫 & 㔯 & గิ & $\underset{-}{\mathbb{G}}$ & $\stackrel{F}{\sigma}$ & 包 & 足 & $\stackrel{m}{\sigma}$ & $\widetilde{E}$ & \begin{tabular}{|l|l|} 
\\
0 \\
0 \\
0
\end{tabular} & \begin{tabular}{|l|}
$\infty$ \\
\hdashline \\
0 \\
0
\end{tabular} & $\begin{array}{l}0 \\
0 \\
0\end{array}$ & $\frac{\nabla}{0}$ & $\begin{array}{l}\mathbb{N} \\
\mathbb{0}\end{array}$ & $\begin{array}{l}0 \\
0 \\
0\end{array}$ & $\begin{array}{l}0 \\
0 \\
0\end{array}$ & $\underset{O}{\stackrel{J}{O}}$ & $\begin{array}{l}0 \\
\dot{E} \\
\dot{\Sigma}\end{array}$ & ్. & 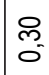 & $\stackrel{?}{=}$ & $\overline{\tilde{N}}$ \\
\hline$I$ & $\begin{array}{l}0 \\
\infty \\
\stackrel{5}{\forall}\end{array}$ & 음 & 옳 & 足 & $\frac{\text { n }}{\mathfrak{N}}$ & $\begin{array}{l}\circ \\
\infty^{\circ} \\
\stackrel{N}{N}\end{array}$ & 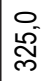 & 兽 & 오ำ & $\begin{array}{l}0 \\
0 \\
8 \\
8\end{array}$ & $\begin{array}{l}10 \\
0 \\
0 \\
0\end{array}$ & $\underset{\mathfrak{Y}}{\dddot{y}}$ & \begin{tabular}{l|}
0 \\
0 \\
0 \\
\end{tabular} & $\begin{array}{l}m \\
m \\
o^{\circ} \\
i\end{array}$ & $\begin{array}{l}1 \\
\infty \\
0 \\
0 \\
\infty\end{array}$ & $\mid \begin{array}{l}\stackrel{+}{\infty} \\
\stackrel{\sim}{\sim}\end{array}$ & $\begin{array}{l}0 \\
\stackrel{y}{y} \\
\mathcal{G}\end{array}$ & \begin{tabular}{|l|}
0 \\
$\mathfrak{y}$ \\
$\mathcal{G}$
\end{tabular} & $\begin{array}{l}0 \\
0 \\
0 \\
\llcorner\end{array}$ & $\mid \begin{array}{l}0 \\
0 \\
0.8 \\
8\end{array}$ & $\begin{array}{l}1 \\
0 \\
0 \\
0\end{array}$ & $\begin{array}{l}10 \\
0 \\
0 \\
\infty\end{array}$ & $\begin{array}{l}0 \\
\text { 옹 } \\
\text { f }\end{array}$ & 采 \\
\hline 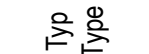 & $\omega$ & $\infty$ & $\omega$ & $\infty$ & 0 & 0 & $\omega$ & $\infty$ & $\infty$ & $\infty$ & $\infty$ & $\infty$ & $\infty$ & $\infty$ & $\infty$ & $\infty$ & $\infty$ & $\infty$ & $\omega$ & $x$ & $a$ & $\infty$ & $\infty$ & $\infty$ \\
\hline 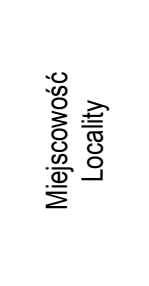 & 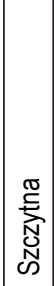 & 울 & 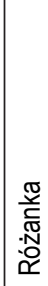 & 空 & 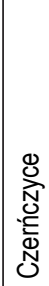 & $\begin{array}{l}\frac{\widetilde{N}}{N} \\
\frac{N}{N} \\
\frac{0}{2} \\
\mathbb{\alpha}\end{array}$ & 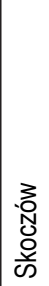 & 高 & $\begin{array}{l}\frac{0}{0} \\
\frac{0}{0} \\
\frac{0}{10} \\
\frac{0}{0} \\
\frac{0}{0} \\
\frac{0}{0}\end{array}$ & 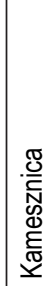 & $\bar{c}$ & 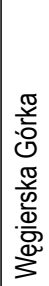 & 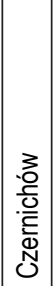 & - & 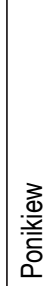 & 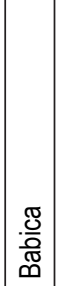 & 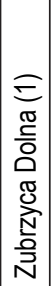 & 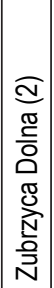 & 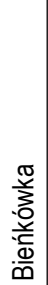 & 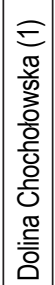 & 造 & :ồ & 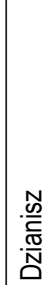 & 岺 \\
\hline 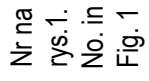 & $\approx$ & $\widetilde{N}$ & $\stackrel{d}{\sim}$ & $\stackrel{2}{\sim}$ & $\stackrel{\sim}{\sim}$ & $\grave{\sim}$ & $\stackrel{\sim}{\sim}$ & $\mathbb{N}$ & স্ল & $\bar{m}$ & $\widetilde{m}$ & m & 产 & $\stackrel{\text { m }}{m}$ & $\ddot{m}$ & $\hat{m}$ & $\infty$ & স্ల & 우 & $\check{\searrow}$ & F & F & 寸 & \& \\
\hline
\end{tabular}




\begin{tabular}{|c|c|c|c|c|c|c|c|c|c|c|c|c|c|c|c|c|c|c|c|c|c|c|c|}
\hline 高 & 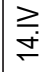 & 言 & $\underset{d}{\grave{d}}$ & $\underset{\infty}{\infty}$ & $\underset{\sim}{\stackrel{2}{N}}$ & $\sum_{\infty}$ & $\underset{\equiv}{\bar{\infty}}$ & $\stackrel{2}{\stackrel{2}{2}}$ & $\rightleftarrows$ & $\rightleftarrows$ & 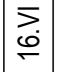 & 오 & 웅 & $\underset{0}{\gtrless}$ & $\geqq$ & $\frac{3}{2}$ & $\gtreqless$ & $\underset{\infty}{\stackrel{\infty}{\infty}}$ & $\underset{\forall}{\sharp}$ & $\underset{\bar{m}}{\equiv}$ & $\begin{array}{l}5 \\
0 \\
\end{array}$ & $\underset{i}{\stackrel{i}{i}}$ & $\sum_{0}$ \\
\hline$\underline{\omega}$ & 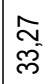 & $\underset{\infty}{\tilde{\sigma}}$ & $\begin{array}{l}\tilde{m} \\
\text { బొ }\end{array}$ & 点 & $\begin{array}{l}0 \\
0 \\
0 \\
0\end{array}$ & $\begin{array}{l}\stackrel{\infty}{\circ} \\
\text { ల్ల }\end{array}$ & 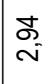 & m & 量 & 量 & $\begin{array}{l}\overline{6} \\
0 \\
\end{array}$ & $\stackrel{m}{\dddot{m}}$ & $\begin{array}{l}\infty \\
\stackrel{0}{\infty} \\
\sim\end{array}$ & $\begin{array}{l}9 \\
9 \\
6\end{array}$ & $\begin{array}{l}\stackrel{8}{R} \\
\stackrel{2}{\circ}\end{array}$ & \begin{tabular}{|l}
$\hat{m}$ \\
$\stackrel{m}{-}$
\end{tabular} & $\frac{\pi}{n}$ & 号 & $\begin{array}{l}\stackrel{8}{0} \\
\stackrel{2}{=}\end{array}$ & $\stackrel{0}{\tilde{N}}$ & \begin{tabular}{|l}
$\infty$ \\
$\infty$ \\
$\rightleftharpoons$
\end{tabular} & 莳 & 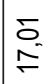 \\
\hline$x^{N}$ & فِ & $\stackrel{N}{\mathrm{E}}$ & $\stackrel{N}{\mathrm{~N}}$ & $N$ & مُ & مֵ & $\stackrel{N}{E}$ & $N$ & $\stackrel{N}{E}$ & $\stackrel{N}{E}$ & $\stackrel{N}{E}$ & $N$ & $\stackrel{N}{\stackrel{N}{E}}$ & $\mathbf{N}$ & $\mathbf{N}$ & $N$ & $\mathbf{N}$ & S & مِ & $N$ & $\mathbf{N}$ & N & | \\
\hline$x^{3}$ & $>$ & $\bar{\Sigma}$ & $>$ & $\equiv$ & $\geq$ & $\geq$ & $\geq$ & $>$ & $>$ & $>$ & $\bar{\Sigma}$ & $\geq$ & $>$ & $>$ & $>$ & $>$ & $\bar{\Sigma}$ & $>$ & $>$ & $>$ & $>$ & $\bar{F}$ & $>$ \\
\hline$u^{\omega}$ & $\begin{array}{l}0 \\
\infty \\
\infty\end{array}$ & $\frac{0}{6}$ & 象 & $\stackrel{\Delta}{=}$ & $\frac{\mathscr{R}}{\tilde{\sigma}}$ & $\widetilde{\widetilde{w}}$ & o & N & $\stackrel{9}{=}$ & $\stackrel{?}{\stackrel{2}{=}}$ & 尔 & $\begin{array}{l}\stackrel{8}{0} \\
\infty \\
\infty\end{array}$ & $\begin{array}{l}\infty \\
\stackrel{\infty}{0} \\
0\end{array}$ & $\begin{array}{l}+ \\
\overline{0} \\
i\end{array}$ & $\begin{array}{l}0 \\
0 \\
0 \\
1\end{array}$ & \begin{tabular}{|l|}
2 \\
0 \\
0 \\
0 \\
1
\end{tabular} & $\begin{array}{l}\mathscr{g} \\
\mathscr{S} \\
6\end{array}$ & $\begin{array}{l}\stackrel{m}{m} \\
m\end{array}$ & $\begin{array}{l}\bar{\sigma} \\
\sigma\end{array}$ & $\begin{array}{l}R \\
m^{-}\end{array}$ & 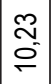 & $\begin{array}{l}\mathscr{L}_{0} \\
\infty \\
\infty\end{array}$ & $\begin{array}{l}\widetilde{m} \\
\tilde{m}\end{array}$ \\
\hline $0^{\star}$ & $\bar{\sigma}$ & б. & $\frac{0}{2}$ & $\stackrel{m}{\sigma}$ & $\underset{\sim}{\stackrel{乛}{\sigma}}$ & $\stackrel{g}{\stackrel{g}{-}}$ & $\stackrel{\infty}{\sim}$ & $\stackrel{g}{\stackrel{g}{-}}$ & 皇 & \& & $\begin{array}{l}\mathscr{Q} \\
\mathscr{2} \\
0\end{array}$ & $\begin{array}{l}0 \\
\infty \\
\sim\end{array}$ & $\stackrel{\substack{f \\
-}}{=}$ & $\overline{\tilde{\sigma}}$ & $\mid \begin{array}{l}\infty \\
0 \\
0 \\
0\end{array}$ & 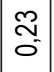 & $\mid \begin{array}{l}n \\
n \\
n\end{array}$ & $\stackrel{5}{=}$ & $\stackrel{\infty}{\sim}$ & $\begin{array}{l}\overline{5} \\
m \\
m\end{array}$ & $\begin{array}{l}8 \\
\stackrel{8}{*}\end{array}$ & $\underset{d}{\mathbb{N}}$ & $\stackrel{0}{=}$ \\
\hline $0^{\Sigma}$ & $\begin{array}{l}\text { กิ } \\
\stackrel{0}{0}\end{array}$ & $\begin{array}{l}\text { ָ } \\
\stackrel{\sim}{\sim} \\
\stackrel{\sim}{N}\end{array}$ & $\begin{array}{l}1 \\
m \\
\infty \\
\infty \\
10 \\
10\end{array}$ & 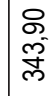 & 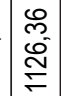 & 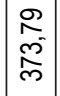 & $\begin{array}{l}0 \\
\stackrel{N}{*} \\
\underset{J}{*}\end{array}$ & $\frac{\bar{N}}{\Sigma}$ & $\begin{array}{l}\text { 芯 } \\
\stackrel{2}{2} \\
\stackrel{2}{2}\end{array}$ & 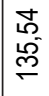 & 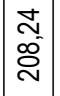 & $\begin{array}{l}\infty \\
\frac{\infty}{0} \\
\frac{0}{0}\end{array}$ & 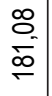 & 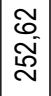 & 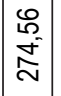 & 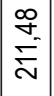 & $\left|\begin{array}{l}\infty \\
\infty \\
\infty \\
10 \\
10\end{array}\right|$ & 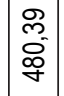 & \begin{tabular}{l}
$\infty$ \\
$\infty$ \\
\multirow{J}{*}{} \\
\end{tabular} & $\begin{array}{l}L \\
\infty \\
\infty \\
\infty \\
0 \\
0\end{array}$ & 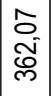 & $\begin{array}{l}\bar{i} \\
\tilde{N} \\
\bar{i}\end{array}$ & 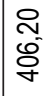 \\
\hline 0 & $\leftleftarrows$ & m & $\begin{array}{l}\infty \\
m \\
0 \\
0\end{array}$ & $\begin{array}{l}2 \\
0 \\
0\end{array}$ & శ్ & \begin{tabular}{|l|}
0 \\
$\infty$ \\
0 \\
0
\end{tabular} & $\stackrel{\cong}{\check{\sigma}}$ & F & 咅 & 竎 & 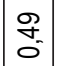 & 8 & 字 & $\mid \begin{array}{l}0 \\
1 \\
0 \\
0\end{array}$ & $\begin{array}{l}8 \\
0\end{array}$ & గ్ & $\begin{array}{l}\mathscr{m} \\
\infty \\
0 \\
0\end{array}$ & $\begin{array}{l}0 \\
\infty \\
0 \\
0\end{array}$ & $\begin{array}{l}0 \\
2 \\
0\end{array}$ & $\begin{array}{l}9 \\
\circ \\
0\end{array}$ & \begin{tabular}{|l|}
$\tilde{2}$ \\
0 \\
0 \\
0
\end{tabular} & $\begin{array}{l}\tilde{R} \\
\tilde{0} \\
0\end{array}$ & 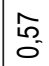 \\
\hline $0^{\stackrel{\times}{e}}$ & ले & $\frac{\nabla}{0}$ & $\stackrel{\text { ల్ }}{\sim}$ & $\tilde{\tilde{c}}$ & 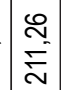 & $\begin{array}{l}\infty \\
\infty \\
\mathbb{E}\end{array}$ & 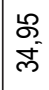 & 货 & 离 & 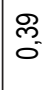 & $\frac{0}{0}$ & $\begin{array}{l}\infty \\
\infty \\
\infty \\
\infty\end{array}$ & $\begin{array}{l}8 \\
0 \\
0\end{array}$ & $\begin{array}{l}\text { 芯 } \\
0\end{array}$ & $\begin{array}{l}0 \\
\mathbb{E} \\
\sim\end{array}$ & $\begin{array}{c}0 \\
\tilde{n} \\
0\end{array}$ & $\mid \begin{array}{l}0 \\
0 \\
0 \\
0\end{array}$ & $\begin{array}{l}\infty \\
\vdots \\
0\end{array}$ & $\begin{array}{r}\hat{0} \\
\text { i }\end{array}$ & $\underset{-}{\check{E}}$ & $\begin{array}{l}5 \\
0 \\
0\end{array}$ & o & $\stackrel{9}{=}$ \\
\hline$\sigma^{\frac{c}{\underline{E}}}$ & $\bar{\delta}$ & O & 卓 & ס & 8 & & 志 & O & $\frac{2}{0}$ & $\frac{\cong}{5}$ & $\bar{\delta}$ & $\stackrel{\infty}{\stackrel{\infty}{\sim}}$ & $\begin{array}{l} \pm \\
\vdots \\
0\end{array}$ & $\begin{array}{l} \\
0 \\
0\end{array}$ & $\begin{array}{l}\infty \\
0 \\
0\end{array}$ & $\begin{array}{l}\tilde{O} \\
\delta \\
0\end{array}$ & $\begin{array}{l}\widetilde{\sigma} \\
\delta \\
0\end{array}$ & $\bar{\delta}$ & $\begin{array}{l}\text { O } \\
0 \\
0\end{array}$ & $\stackrel{2}{0}$ & $\begin{array}{l}28 \\
0 \\
0\end{array}$ & $\bar{\delta}$ & $\begin{array}{l}\infty \\
0 \\
0 \\
0\end{array}$ \\
\hline$\sigma^{-i_{n}}$ & $\bar{ָ}$ & $\begin{array}{l}2 \\
0 \\
0\end{array}$ & $\stackrel{10}{=}$ & 8 & $\begin{array}{l}\infty \\
\infty \\
\infty\end{array} \mid$ & $\begin{array}{l}\frac{L}{2} \\
\frac{1}{5}\end{array}$ & $\begin{array}{l}\tilde{\sigma} \\
\stackrel{5}{-}\end{array}$ & 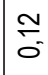 & N & N్ & $\begin{array}{l}0 \\
0 \\
0\end{array}$ & 尔 & $\begin{array}{l}0 \\
\tilde{y} \\
0\end{array}$ & 좀 & $\begin{array}{l}\text { t } \\
\text { o }\end{array}$ & $\stackrel{\Xi}{\square}$ & $\begin{array}{l}\infty \\
0 \\
0\end{array}$ & $\frac{0}{0}$ & $\begin{array}{l}\tilde{m} \\
\tilde{O} \\
0\end{array}$ & 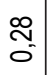 & $\stackrel{\square}{\check{\sigma}}$ & o & 守 \\
\hline I & 용 & 离 & 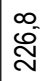 & 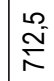 & $\mid \begin{array}{l}0 \\
5 \\
8 \\
8\end{array}$ & $\begin{array}{l}0 \\
10 \\
0 \\
8\end{array}$ & 웅 & $\begin{array}{l}0 \\
0 \\
0 \\
60\end{array}$ & $\frac{0}{20}$ & 高 & $\stackrel{\circ}{\stackrel{్}{N}}$ & 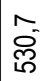 & $\begin{array}{l}0 \\
\frac{0}{1} \\
i\end{array}$ & $\begin{array}{l}0 \\
0 \\
0\end{array}$ & $\mid \begin{array}{l}n \\
-5 \\
6\end{array}$ & 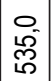 & 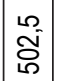 & 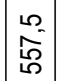 & $\begin{array}{l}0 \\
\stackrel{0}{2} \\
\text { ษ }\end{array}$ & $\begin{array}{l}0 \\
0 \\
0 \\
0\end{array}$ & $\begin{array}{l}0 \\
0 \\
0 \\
0\end{array}$ & $\begin{array}{l}0 \\
0 \\
0 \\
0\end{array}$ & 吕 \\
\hline 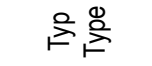 & $\infty$ & $\infty$ & $צ$ & $\infty$ & $\infty$ & $צ$ & $\omega$ & $\omega$ & 0 & $\infty$ & $\omega$ & 0. & $\infty$ & $\infty$ & $\infty$ & $\infty$ & $\infty$ & $\infty$ & $\infty$ & $\infty$ & $\infty$ & $\infty$ & $\infty$ \\
\hline 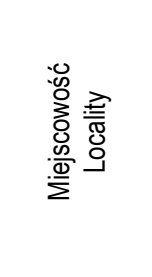 & 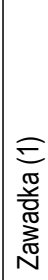 & $\begin{array}{l}: \mathbb{N} \\
: \frac{N}{5} \\
\text { के }\end{array}$ & $\begin{array}{l}\text { 紊 } \\
\text { 产 }\end{array}$ & 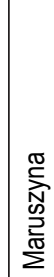 & 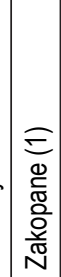 & 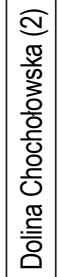 & 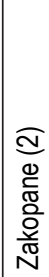 & 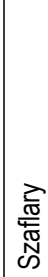 & 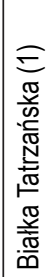 & 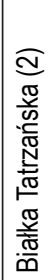 & 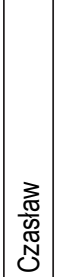 & 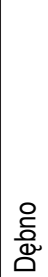 & 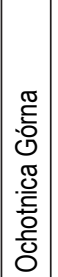 & 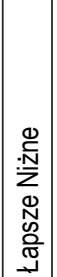 & 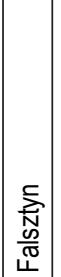 & \begin{tabular}{|l|}
$\frac{\mathbb{N}}{N}$ \\
$\frac{\mathbb{N}}{Z}$ \\
$\frac{\mathbb{U}}{Z}$
\end{tabular} & 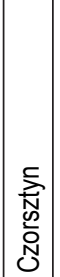 & 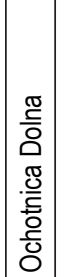 & $\stackrel{\oplus}{\stackrel{\Xi}{\Sigma}}$ & 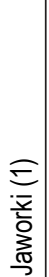 & 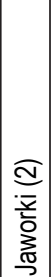 & 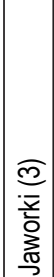 & 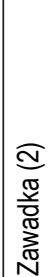 \\
\hline 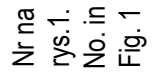 & $\mathscr{q}$ & 于 & $\stackrel{\infty}{+}$ & প্ & in & 5 & กิ & గొ & के & 识 & $\infty$ & in & $\infty$ & i & 8 & $\overline{6}$ & $\widetilde{\mathcal{O}}$ & $\mathbb{0}$ & 8 & 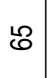 & 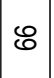 & $\hat{0}$ & $\infty$ \\
\hline
\end{tabular}




\begin{tabular}{|c|c|c|c|c|c|c|c|c|c|c|c|c|c|c|c|c|}
\hline 몸 & $\overrightarrow{0}$ & $\underset{\text { N }}{\bar{N}}$ & ते & $\vec{\sim}$ & $\underset{0}{\infty}$ & $\begin{array}{l}\text { 三 } \\
\text { ¿े }\end{array}$ & ते & 응 & $\overline{\bar{\sim}}$ & 응 & $\underset{\sim}{\grave{d}}$ & 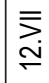 & $\equiv$ & $\geqq$ & $\equiv$ & 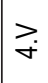 \\
\hline$\underline{\rho}$ & $\stackrel{8}{E}$ & $\bar{\sigma}$ & $\begin{array}{l}\text { 오 } \\
\text { Ð }\end{array}$ & \begin{tabular}{l}
$\widehat{\infty}$ \\
\multirow{\sigma}{*}{}
\end{tabular} & $\begin{array}{l}\text { \$ } \\
\infty \\
\infty \\
\sim\end{array}$ & $\frac{\sigma}{\check{\Sigma}}$ & 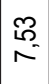 & 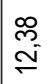 & $\begin{array}{l}\infty \\
\infty \\
\infty \\
\infty\end{array}$ & 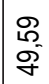 & $\underset{\mathcal{N}}{\tilde{\sigma}}$ & $\frac{\sigma}{\infty^{-}}$ & 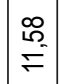 & $\begin{array}{l}0 \\
\dot{q} \\
\underline{2}\end{array}$ & $\begin{array}{l}\widetilde{1} \\
\infty \\
0 \\
0\end{array}$ & $\stackrel{\mathscr{S}}{\stackrel{2}{-}}$ \\
\hline$x^{N}$ & فِ & $\stackrel{N}{E}$ & $\stackrel{N}{E}$ & $N$ & $\stackrel{N}{\mathrm{E}}$ & $\mathbf{N}$ & $\stackrel{N}{E}$ & $\stackrel{N}{E}$ & فِ & ف & $N$ & $\stackrel{N}{\mathrm{E}}$ & $N$ & $\stackrel{N}{E}$ & $N$ & ف \\
\hline$x^{3}$ & $\equiv$ & $>$ & $>$ & $>$ & $\bar{\Sigma}$ & $\equiv$ & $\equiv$ & $\bar{\Sigma}$ & $>$ & $\equiv$ & $>$ & $>$ & $>$ & $>$ & $>$ & $>$ \\
\hline$u^{\omega}$ & 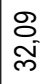 & $\frac{1}{0}$ & 8 & $\begin{array}{l}\infty \\
0 \\
0\end{array}$ & 心్ & $\begin{array}{c}\bar{j} \\
\sim\end{array}$ & $\overline{\tilde{m}}$ & $\stackrel{8}{=}$ & 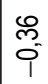 & $\stackrel{\leftrightarrow}{\circ}$ & $\stackrel{\infty}{-}$ & $\underset{\tilde{m}}{\bar{m}}$ & $\begin{array}{l}0 \\
0 \\
0 \\
0 \\
1\end{array}$ & 음 & $\begin{array}{l}0 \\
0 \\
0\end{array}$ & $\begin{array}{l}8 \\
10 \\
\infty \\
\infty\end{array}$ \\
\hline $0^{\sigma}$ & $\underset{\forall}{\stackrel{8}{*}}$ & 8 & 票 & $\stackrel{8}{\mathscr{E}}$ & $\cong$ & $\stackrel{\mathcal{F}}{\leftarrow}$ & Ö. & m & in & $\stackrel{\mathbb{N}}{=}$ & $\stackrel{5}{5}$ & $\underset{N}{\mathbb{N}}$ & $\begin{array}{l}2 \\
0 \\
0\end{array}$ & 8 & $\begin{array}{l}\infty \\
\infty \\
0 \\
0\end{array}$ & $\frac{\pi}{N}$ \\
\hline $0^{\Sigma}$ & 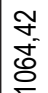 & $\begin{array}{l}9 \\
8 \\
8\end{array}$ & $\frac{\Sigma}{E}$ & $\begin{array}{l}\text { R } \\
\overline{8} \\
\bar{d}\end{array}$ & 怘 & 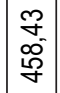 & 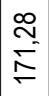 & $\underset{N}{\mathbb{N}}$ & 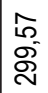 & $\mid \begin{array}{l}10 \\
50 \\
0 \\
0\end{array}$ & $\begin{array}{l}\stackrel{\infty}{\sim} \\
\underset{\sim}{\sim}\end{array}$ & 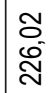 & $\underset{\Sigma}{\Sigma}$ & $\begin{array}{l}0 \\
\stackrel{0}{\circ}\end{array}$ & $\begin{array}{l}\text { N } \\
\text { 侻 } \\
\text { N }\end{array}$ & $\begin{array}{l}0 \\
\stackrel{n}{N} \\
\stackrel{n}{N}\end{array}$ \\
\hline 0 & $\stackrel{2}{\sim}$ & $\stackrel{2}{N}$ & 采 & 它 & $\begin{array}{l}0 \\
10 \\
0\end{array}$ & $\begin{array}{l}0 \\
0 \\
0 \\
0\end{array}$ & $\begin{array}{c}\bar{m} \\
0 \\
0\end{array}$ & $\begin{array}{l}10 \\
0 \\
0\end{array}$ & $\begin{array}{l}\text { E } \\
0 \\
0\end{array}$ & $\underset{+}{\mp}$ & $\begin{array}{l}\infty \\
0 \\
0 \\
0\end{array}$ & $\begin{array}{c}\hat{n} \\
0\end{array}$ & $\begin{array}{l}\text { I } \\
0 \\
0\end{array}$ & 告 & 政 & 苛 \\
\hline$\sigma^{\stackrel{\times}{\underline{m}}}$ & $\begin{array}{l}\infty \\
\infty \\
0\end{array}$ & $\stackrel{\infty}{5}$ & ฮิ & 足 & 兽 & $\begin{array}{l}\hat{n} \\
0 \\
0\end{array}$ & $\stackrel{1}{\sigma}$ & ON & o̊ & స్ & $\begin{array}{l}\infty \\
\stackrel{0}{0} \\
0\end{array}$ & $\stackrel{\substack{0 \\
\sim}}{\sim}$ & $\stackrel{\tilde{m}}{\sigma}$ & 灾 & $\begin{array}{l}m \\
0 \\
0\end{array}$ & $\begin{array}{l}0 \\
0 \\
0\end{array}$ \\
\hline$\sigma^{\frac{c}{E}}$ & 8 & \& & o & ్ㅗ & $\bar{\delta}$ & $\bar{\delta}$ & ¿̊. & O & ช్ & 8 & 응 & 豙 & $\stackrel{\cong}{\check{0}}$ & O & ช్ & 응 \\
\hline $0^{i 5}$ & $\stackrel{\circ}{\circ}$ & E & 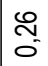 & $\begin{array}{l}0 \\
0 \\
0\end{array}$ & ช & $\mid \begin{array}{l}\infty \\
0 \\
0\end{array}$ & $\begin{array}{l}8 \\
0 \\
0\end{array}$ & 8 & 8 & 낭 & $\underset{0}{\mathbb{N}}$ & L & $\begin{array}{l}\Re \\
\tilde{0} \\
0\end{array}$ & $\frac{9}{0}$ & 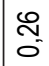 & F \\
\hline I & ণ্. & 옹 & O & 唄 & 吕 & $\begin{array}{l}0 \\
\stackrel{0}{0} \\
\sim\end{array}$ & 움 & ì & $\begin{array}{l}0 \\
0 \\
50 \\
i 5\end{array}$ & $\frac{0}{20}$ & $\begin{array}{l}\text { 음 } \\
\text { ơ } \\
\text { p }\end{array}$ & \begin{tabular}{l}
0 \\
0 \\
\hdashline \\
\hdashline
\end{tabular} & 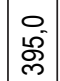 & $\begin{array}{l}\text { 음 } \\
\text { ò }\end{array}$ & 웅 & $\begin{array}{l}0 \\
08 \\
08\end{array}$ \\
\hline 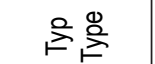 & $\omega$ & $\infty$ & $\infty$ & $\infty$ & $\infty$ & $\infty$ & $\infty$ & $\infty$ & $\infty$ & $\infty$ & $\infty$ & $\infty$ & $\infty$ & $\infty$ & $\infty$ & $\infty$ \\
\hline 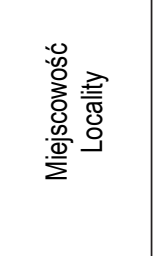 & 옳 & $\begin{array}{l}3 \\
\text {. } \\
\text {. } \\
\text { \& }\end{array}$ & 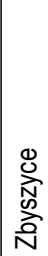 & 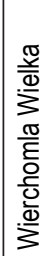 & 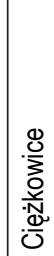 & 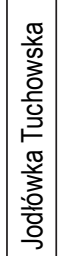 & $\frac{\vec{\pi}}{\underline{\pi}}$ & 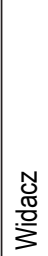 & 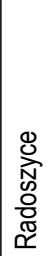 & 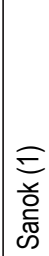 & 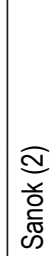 & 意 & 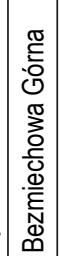 & \begin{tabular}{|l}
$\frac{0}{N}$ \\
$\frac{\mathbb{N}}{0}$ \\
$\frac{0}{0}$ \\
N
\end{tabular} & 胥 & 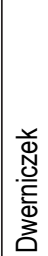 \\
\hline 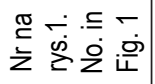 & 8 & 웅 & $\bar{N}$ & $\approx$ & $\Re$ & ホ & $\stackrel{20}{R}$ & 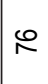 & $\hat{N}$ & $\infty$ & R & $\infty$ & $\infty$ & 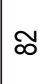 & $\varlimsup_{\infty}$ & \$ \\
\hline
\end{tabular}

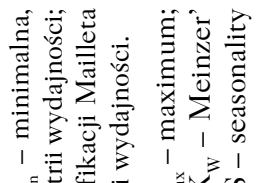

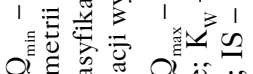

वंहू

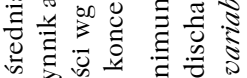

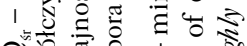

a) क्षे $1, \frac{n}{b} \equiv$

का

हैं ن

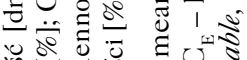

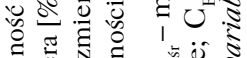

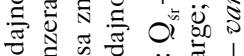

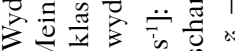

$\because 1 \quad \vec{b} \ddot{z}$

घํํำ

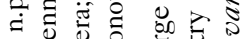

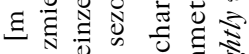

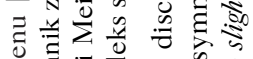

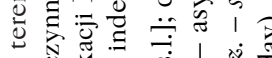

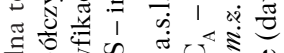

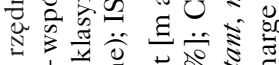

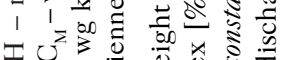

نั

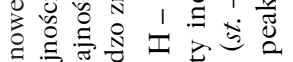

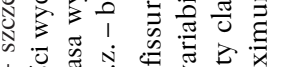

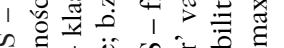

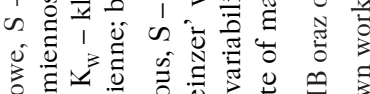

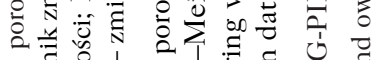

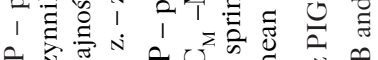

a jo

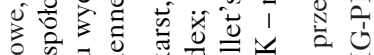

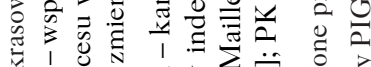

$\pm 100$

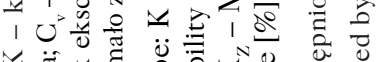

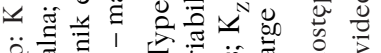

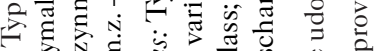

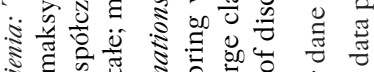

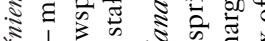

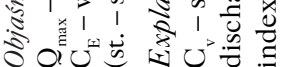



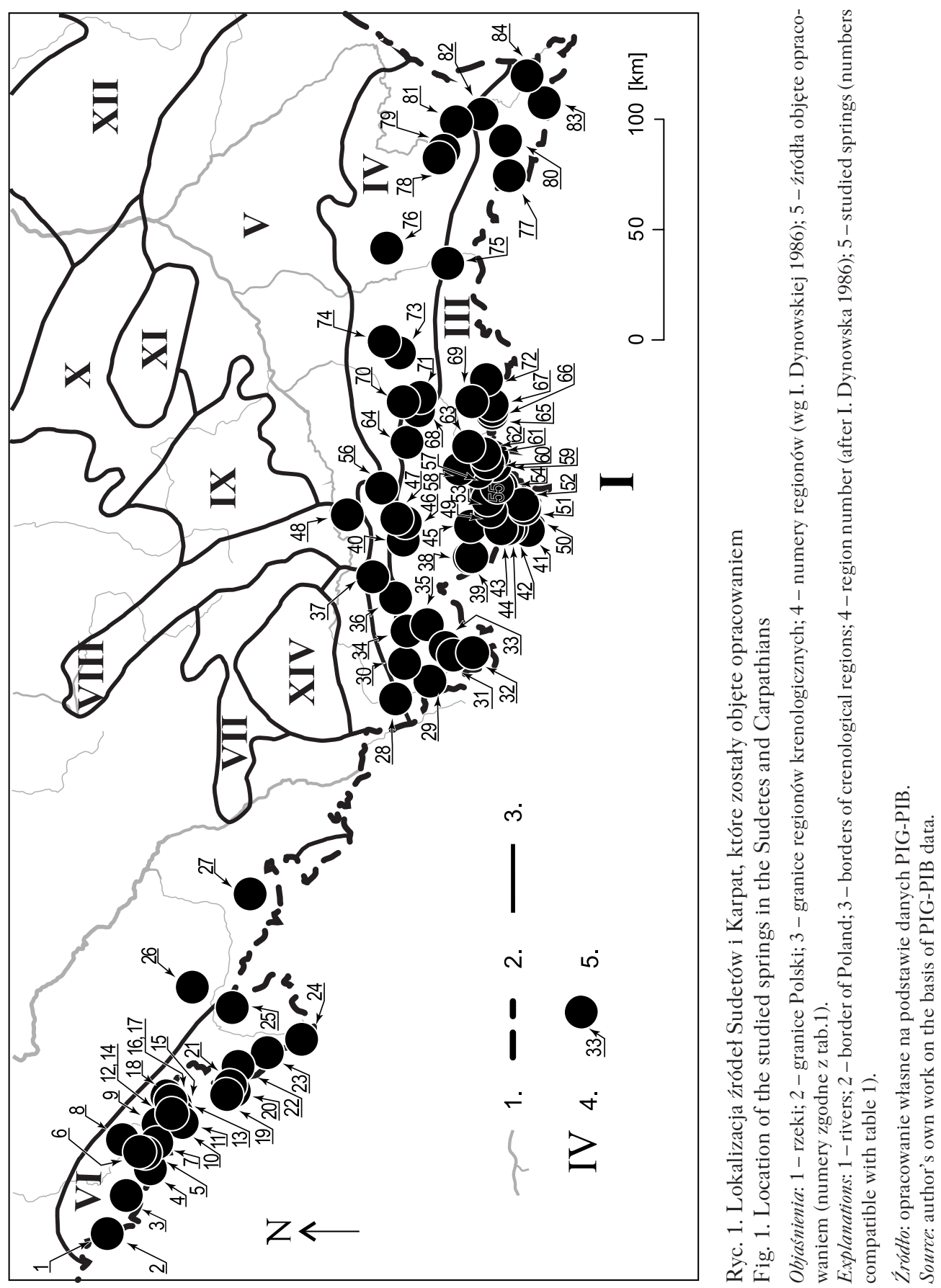
Obniżenie Orawsko-Podhalańskie (15). Zlewnie podziemne źródeł najczęściej zbudowane są z utworów wieku paleogeńskiego (35) i kredowego (13), najrzadziej zaś z osadów plejstoceńskich (3). Wodonoścem są najczęściej łupki, piaskowce i piaski (60\% wypływów), rzadziej osady węglanowe (19\%) oraz skały magmowe (15\%) czy okruchowe (6\%).

Rzędne wypływów zawierają się pomiędzy 227 a 965 m n.p.m., przy czym źródła sudeckie leżą przeciętnie na wysokości 518,7 m n.p.m., a karpackie - 548,1 m n.p.m. W obu grupach przeważają wypływy położone w obrębie masywów górskich - na przedgórzach i w zapadliskach leży $47 \%$ źródeł karpackich i tylko 15\% sudeckich. Na podstawie litologicznych i stratygraficznych cech wodonośca wypływy badanej próby zaklasyfikowano do trzech podstawowych typów hydrogeologicznych: szczelinowych (76 źródeł), porowych (5) i krasowych (3).

Podstawą analizy zmienności wydajności źródeł były szeregi minimów, średnich oraz maksimów miesięcznych uzyskane na bazie pomiarów terminowych wykonywanych z niejednakową regularnością (przeważnie raz w tygodniu). Obliczono współczynniki zmienności wydajności (Kř̌́ž 1973; Kresic, Stevanowic 2010):

wg K. Pearsona $\left(C_{V}\right)$ :

$$
C_{V}=\frac{O s_{Q}}{S r_{Q}}
$$

wg R. Mailleta $\left(C_{R}\right)$ :

$$
C_{R}=\frac{M x_{Q}}{M n_{Q}}
$$

oraz wg O.E. Meinzera $\left(C_{M}\right)$ :

$$
C_{M}=\frac{M x_{Q}-M n_{Q}}{S r_{Q}} \cdot 100 \%
$$

gdzie:

$O s_{Q}$ - odchylenie standardowe średnich miesięcznych wydajności;

$M x_{Q}, S r_{Q}, M n_{Q}$ - odpowiednio: wydajność maksymalna, średnia, minimalna.

Do analizy sezonowości wydajności wypływów zastosowano wykresy typu „pudełko z wąsami” oraz tzw. indeksy Markhama. Indeks sezonowości (IS) odzwierciedla stopień nierównomierności wydajności w ciągu przeciętnego roku (Markham 1970). Przybiera on wartości z przedziału 0-100\%, przy czym 0\% oznacza, że wydajność źródła jest równomiernie rozłożona, a 100\% - że jest skupiona tylko w jednym miesiącu w ciągu całego roku. Natomiast pora koncentracji (PK) wskazuje miesiąc będący wypadkową (z wektorowo rozumianych) wydajności we wszystkich miesiącach roku. Nie należy jej jednak utożsamiać z maksimum średniej miesięcznej 
wydajności (Tomalski, Tomaszewski 2015). Ponieważ źródła obserwowano w różnych latach, niemożliwe było przyjęcie synchronicznych okresów odniesienia. Miary sezonowości obliczono więc dla dostępnych długości serii, jednak obejmujących więcej niż 3 lata.

Przeanalizowano ponadto wybrane charakterystyki rozkładów wydajności źródeł, obliczając w tym celu współczynnik asymetrii $\left(C_{A}\right)$ (Tomalski, Tomaszewski 2015):

$$
C_{A}=\frac{N \cdot \sum_{i=1}^{N}\left(Q_{i}-S r_{Q}\right)^{3}}{O s_{Q}{ }^{3} \cdot(N-1) \cdot(N-2)}
$$

oraz współczynnik ekscesu (kurtozy; $\left.C_{E}\right)$ :

$$
C_{E}=\frac{N \cdot(N+1) \cdot \sum_{i=1}^{N}\left(Q_{i}-S r_{Q}\right)^{4}-3 \cdot \sum_{i=1}^{N}\left(Q_{i}-S r_{Q}\right)^{2} \cdot \sum_{i=1}^{N}\left(Q_{i}-S r_{Q}\right)^{2} \cdot(N-1)}{O s_{Q}{ }^{4}(N-1) \cdot(N-2) \cdot(N-3)}
$$

gdzie:

$O s_{Q}$ - odchylenie standardowe średnich miesięcznych wydajności,

$Q i-$ wydajność i-tego źródła w próbce,

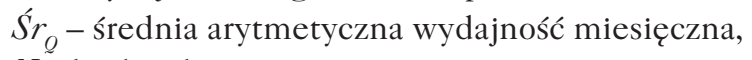

$N$ - liczba obserwacji.

\section{Wyniki i dyskusja}

W zbadanej grupie wypływów przeważają źródła VI klasy wydajności wg Meinzera (53\%). Większych źródeł, ze średnią wydajnością przekraczającą $10 \mathrm{dm}^{3} \cdot \mathrm{s}^{-1}$ (klasa IV), jest 6, a największym (klasa III) jest wywierzysko Chochołowskie (nr 41, $241 \mathrm{dm}^{3} \cdot \mathrm{s}^{-1}$ ). Wydajność aż 14 wypływów mieści się poniżej $0,1 \mathrm{dm}^{3} \cdot \mathrm{s}^{-1}$ (klasa VII). Wśród najmniejszych źródeł dominują wypływy karpackie - przeciętne wydajności mieszczą się zazwyczaj w przedziale $0,1-1,0 \mathrm{dm}^{3} \cdot \mathrm{s}^{-1}$ (klasa VI), podczas gdy wypływy sudeckie są zazwyczaj bardziej wydajne (klasa $\left.\mathrm{V}-1,0-10 \mathrm{dm}^{3} \cdot \mathrm{s}^{-1}\right)$.

Współczynnik zmienności wydajności wg Mailleta $\left(\mathrm{C}_{\mathrm{R}}\right)$ dla źródeł stale bijących zmieniał się w szerokim zakresie: od 1,6 do ponad 2 tysięcy. Spośród 84 wypływów tylko źródło w Czerńczycach (nr 26) można zakwalifikować do wypływów o stałej wydajności $\left(\mathrm{C}_{\mathrm{R}}=1,6\right)$. Niewielką zmiennością $\left(\mathrm{C}_{\mathrm{R}}<3\right)$ odznacza się także wydajność źródeł w Rudziczce (nr 27), Rożnowie (nr 70) i w Szczytnej (nr 22). Wg klasyfikacji Mailleta źródeł mało zmiennych $\left(2<\mathrm{C}_{\mathrm{R}}<10\right)$, zmiennych $\left(10<\mathrm{C}_{\mathrm{R}}<50\right)$ i bardzo zmiennych $\left(\mathrm{C}_{\mathrm{R}}>50\right)$ jest w tej populacji niemal tyle samo (po 33\% ogółu wypływów). Wśród tej ostatniej grupy znajdują się 3 źródła okresowo zanikające: w Zakopanem 1 (nr 50), Rytrze (nr 69) i Sanoku 1 (nr 78). 
Nieco inny obraz daje wskaźnik zmienności Meinzera $\left(\mathrm{C}_{\mathrm{M}}\right)$. Według tego kryterium brak jest źródeł stałych $\left(0<\mathrm{C}_{\mathrm{M}}<25 \%\right)$, zaledwie 4 źródła należą do mało zmiennych $\left(25 \%<\mathrm{C}_{\mathrm{M}}<100 \%\right)$, natomiast aż 80 wypływów to źródła zmienne $\left(\mathrm{C}_{\mathrm{M}}>100 \%\right)$. Także i w tym przypadku największa stabilność wydatku cechuje podsudeckie Czerńczyce $\left(\mathrm{C}_{\mathrm{M}}=53 \%\right)$, zaś za najbardziej zmienne należy uważać źródła w Dwerniczku (nr 84), Ponikwi (nr 36), Zakopanem 1 (nr 50), Dobromyślu 2 (nr 14) i Rytrze (nr 69).

Analogiczne wnioski płyną z zastosowania kryterium Pearsona - małą zmiennością $\left(0<\mathrm{C}_{\mathrm{V}}<0,2\right)$ charakteryzują się 4 źródła, przeciętną $\left(0,2<\mathrm{C}_{\mathrm{V}}<0,4\right)-16$, dużą $\left(0,4<\mathrm{C}_{\mathrm{V}}<1,0\right)-55$, bardzo dużą $\left(1,0<\mathrm{C}_{\mathrm{v}}<1,5\right)-8$ i skrajnie dużą $\left(\mathrm{C}_{\mathrm{v}}>1,5\right)-$ jedno źródło (Kowary 1 - nr 5). Oprócz wymienionych powyżej, w grupie źródeł o bardzo dużej zmienności znalazły się także wypływy w Sanoku 1 (nr 78) i Czermnej (nr 19).

Z porównania współczynników zmienności wydajności źródeł Sudetów i Karpat wynika, że jej dynamika maleje w kierunku wschodnim. Przeciętne współczynniki zmienności sudeckich wypływów są bowiem nieco wyższe $\left(\mathrm{C}_{\mathrm{V}}=0,66, \mathrm{C}_{\mathrm{R}}=28,1\right.$, $\left.\mathrm{C}_{\mathrm{M}}=363 \%\right)$ niż źródeł karpackich $\left(\mathrm{C}_{\mathrm{V}}=0,57, \mathrm{C}_{\mathrm{R}}=19,4, \mathrm{C}_{\mathrm{M}}=275 \%\right)$. Jednak wewnątrz obu grup zaznaczają się różnice - wypływy Przedgórza Sudeckiego cechuje wyraźnie mniejsza niż w samych Sudetach zmienność wydajności, podczas gdy źródła Karpat wykazują więcej podobieństw (ryc. 2). Istotne są także uwarunkowania hydrogeologiczne - mimo znaczących różnic w liczebności grup, współczynniki zmienności źródeł porowych okazały się od 1,2 do 2,1 razy mniejsze od analogicznych miar obliczonych dla wypływów krasowych i od 2,3 do 7,5 razy mniejsze aniżeli dla źródeł szczelinowych. Potwierdza to kluczową rolę utworów wodonośnych w transformacji opadu i kształtowaniu odpływu podziemnego. Wodonośce szczelinowe, szczególnie te związane z fliszem karpackim, cechuje niewielka zasobność i szybkie tempo wymiany wody (Jokiel 1997). Natomiast zbiorniki krasowe odznaczają się głębszym krążeniem oraz większą na ogół zasobnością, a porowe - wolniejszym tempem recesji, co w obu przypadkach wpływa znacząco na stabilizację wydajności zasilanych nimi źródeł.

Stwierdzono ujemną tendencję zależności pomiędzy wydajnością wypływu a jej współczynnikami zmienności, która jednak w tej populacji nie przekroczyła progu istotności. W nieco większym stopniu $(\mathrm{r}=-0,22)$ zmienność wydajności zależy od jej minimalnego poziomu $\left(Q_{\min }\right)$. Ujemny kierunek tych zależności jest potwierdzeniem, iż małe źródła charakteryzują się większymi wahaniami wydajności niż duże, zasilane z bardziej zasobnych zbiorników wód podziemnych. Dotyczy to nie tylko wypływów szczelinowych, ale także źródeł i wywierzysk krasowych z obszaru wyżyn. Do stałych i mało zmiennych należą zarówno źródła Wyżyny Krakowsko-Częstochowskiej (Chełmicki 2001; Siwek 2013), jak i Wyżyny Lubelskiej (Michalczyk, Turczyński 1999; Michalczyk i in. 2008). Duże źródła krasowe cechuje bowiem wolniejsze tempo recesji wydajności (Barczyk 2008) oraz dłuższy czas wymiany wody w zlewni. Wśród wypływów Sudetów i Karpat stwierdzono ponadto bardzo słabą zależność pomiędzy zmiennością wydajności a rzędną wypływu $(\mathrm{r}=0,16)$. Położone niżej źródła mogą 

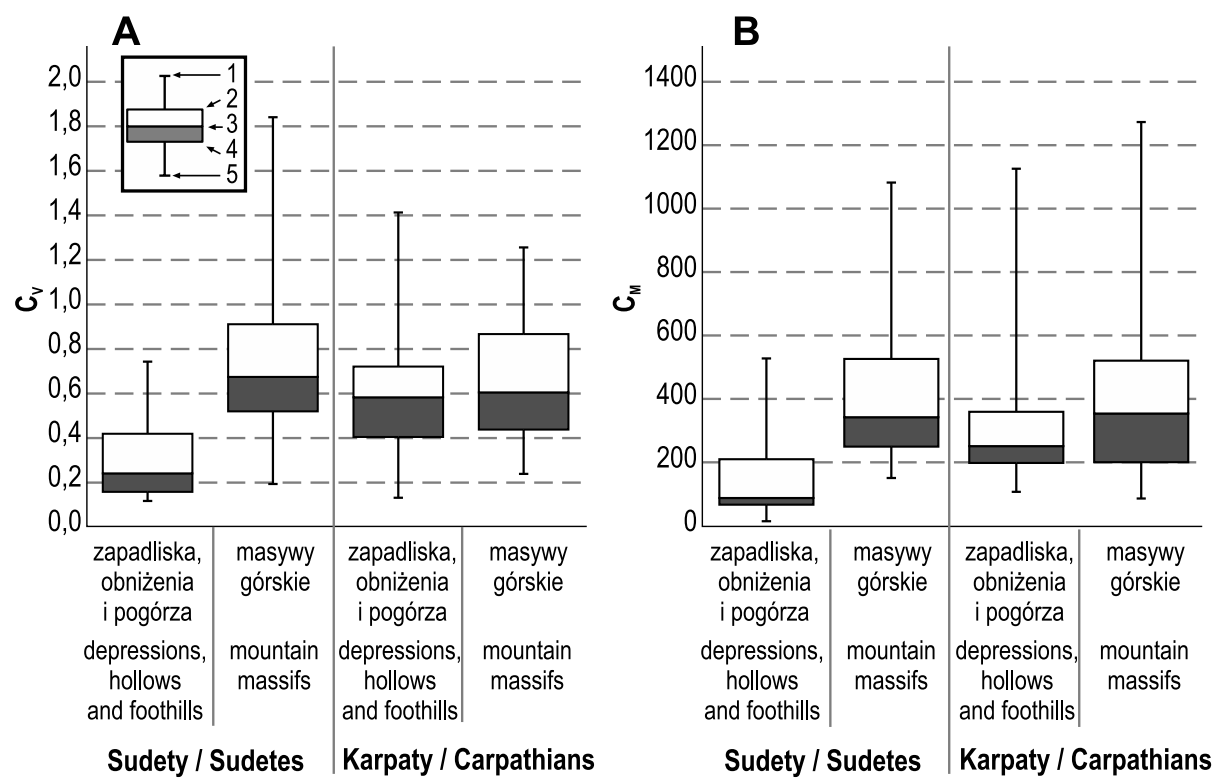

Ryc. 2. Charakterystyki rozkładów zmienności wydajności źródeł Sudetów i Karpat: A - współczynnik zmienności Pearsona $\left(\mathrm{C}_{\mathrm{V}}\right) ; \mathrm{B}$ - współczynnik zmienności Meinzera $\left(\mathrm{C}_{\mathrm{M}}\right)[\%]$ Fig. 2. Main distribution characteristics of spring discharge variability in the Sudetes and Carpathians: $\mathrm{A}$ - spring variability index $\left(\mathrm{C}_{\mathrm{v}}\right) ; \mathrm{B}-$ Meinzer' variability index $\left(\mathrm{C}_{\mathrm{M}}\right)[\%]$ Objaśnienia: 1 - maksimum; 2 - trzeci kwartyl; 3 - mediana; 4 - pierwszy kwartyl; 5 - minimum. Explanations: 1 - maximum; 2 - third quartile; 3 - median; 4 - first quartile; 5 - minimum. Źródto: opracowanie własne na podstawie danych PIG-PIB.

Source: author's own work on the basis of PIG-PIB data.

bowiem drenować poziom wodonośny o większej miąższości, a ich wydajność jest słabiej uzależniona od rozkładu opadów atmosferycznych.

Przeanalizowano także sezonową zmienność wydajności wypływów, których długość serii pomiarowych przekroczyła 36 miesięcy. Indeks sezonowości Markhama obliczony dla 77 źródeł zmieniał się od 0,65 (Czerńczyce - nr 26) do blisko 50\% (okresowe źródło w Sanoku 1 - nr 78). Mimo iż indeks sezonowości okazał się niezależny od średniej wydajności wypływu, stwierdzono istotny związek pomiędzy tą miarą a współczynnikami zmienności wydajności: Pearsona $(r=0,73)$ oraz Meinzera $(r=0,40)$. Oznacza to, że źródła o większej dynamice wydajności odznaczają się także jej wyraźnym zróżnicowaniem sezonowym. 
Na zbieżność pomiędzy wartościami współczynnika zmienności i indeksu sezonowości zwrócił już uwagę Jokiel (1997), badając reżim wydajności źródeł karpackich. Źródła zmienne charakteryzują się wyższym indeksem sezonowości wydajności. Potwierdza to zależność skali zmienności wydatku od wielkości drenowanego zbiornika. Jednak zarówno współczynniki zmienności, jak i indeks sezonowości nie są związane z wielkością wydatku źródeł.

Podobnych wniosków dostarcza analiza parametrów rozkładów wydajności wypływów. W większości przypadków rozkłady są symetryczne lub wykazują niewielką asymetrię prawostronną $\left(\mathrm{C}_{\mathrm{A}}>0\right)$. Mediany współczynników asymetrii wydajności źródeł sudeckich i karpackich są zbliżone i wynoszą odpowiednio $\mathrm{C}_{\mathrm{A}}=1,95$ i $\mathrm{C}_{\mathrm{A}}=1,68$. W Sudetach zatem nieznacznie częściej zdarzają się ekscesy maksymalne, bowiem tutejsze źródła odznaczają się wyższą zmiennością wydajności. W obu grupach widoczne są także różnice pomiędzy wypływami gór i ich przedpola - wydajność wyżej położonych źródeł charakteryzuje się większą asymetrią oraz wyższym współczynnikiem ekscesu (ryc. 3). Dynamika wypływów „górskich” jest bowiem bardziej zależna od rozkładu opadów atmosferycznych aniżeli źródeł kotlin i pogórza. Czas reakcji zazwyczaj jest liczony w dniach, ale warto podkreślić, że wypływy pozornie jednolitego masywu górskiego mogą całkiem odmiennie reagować na zasilanie. Ponadto, niżej położone źródła są niekiedy przykryte warstwą koluwiów bądź aluwiów, mają więc często charakter zakryty (filtracyjny), co umożliwia także pośrednie ich zasilanie z więcej niż jednego poziomu wodonośnego (Humnicki 2006).

Obie miary rozkładu wydajności z oczywistych względów (matematycznej wzajemnej zależności) charakteryzują się bardzo wysoką dodatnią korelacją $(r=0,91)$. Źródła zmienne i bardzo zmienne cechują się większą liczbą wydajności odstających. Nierzadko w czasie pomiaru wydajności maksymalnych rejestrowany jest spływ podpowierzchniowy, a czasami również powierzchniowy, których wpływu na wydajność rejestrowaną w przekroju pomiarowym nie sposób wyeliminować (Małecka 1997). Najwyższym wskaźnikiem asymetrii rozkładu $\left(\mathrm{C}_{\mathrm{A}}>5\right)$ odznaczają się źródła o bardzo dużej zmienności: w Dwerniczku (nr 84), Karpaczu (nr 4) i Kowarach 1 (nr 5).

Pora koncentracji odpływu jest jeszcze bardziej zróżnicowana niż indeks sezonowości. Ponieważ wydajność źródła jest funkcją zasilania zbiornika wód podziemnych, największe wydatki źródeł notowano wiosną, w okresie maksymalnego napełnienia wodonośca (ryc. 4). Najczęściej koncentracja wydajności osiągana jest w marcu (25\% wypływów) i kwietniu (23\%), co podkreśla rolę zasilania roztopowego w bilansie warstwy wodonośnej. Przeciętna data koncentracji wydajności wypada 30 kwietnia, a skrajne daty obejmują okres od 23 lutego do 22 sierpnia. Wyjątek stanowi Wywierzysko Chochołowskie (nr 41), którego pora koncentracji wydajności przypada na listopad. Obszar zasilania jego zlewni podziemnej sięga bowiem strefy późnego występowania roztopów, a ponadto dopływ ma miejsce przede wszystkim w ciepłej połowie roku. Drugim wypływem z wyraźnie późniejszą porą koncentracji wydajności jest źródło 

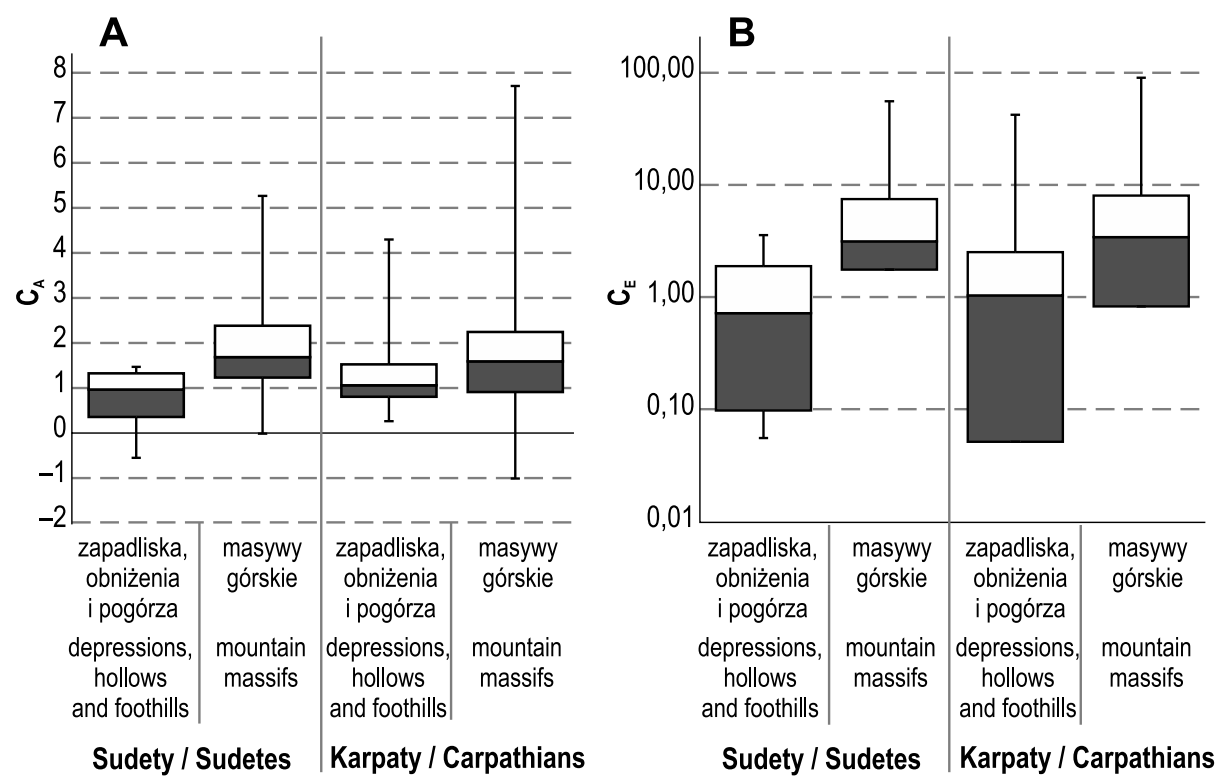

Ryc. 3. Charakterystyki rozkładów wydajności źródeł Sudetów i Karpat: A - współczynnik asymetrii Pearsona $\left(\mathrm{C}_{\mathrm{A}}\right) ; \mathrm{B}$ - współczynnik ekscesu $\left(\mathrm{C}_{\mathrm{E}}\right)$

Fig. 3. Main distribution characteristics of spring discharge in the Sudetes and Carpathians: A - asymmetry $\left(\mathrm{C}_{\mathrm{A}}\right) ; \mathrm{B}-$ kurtosis $\left(\mathrm{C}_{\mathrm{E}}\right)$

Objaśnienia: jak na ryc. 2.

Explanations: as in Fig. 2.

Źródto: opracowanie własne na podstawie danych PIG-PIB.

Source: author's own work on the basis of PIG-PIB data.

w Skoczowie (nr 28), jednak w tym przypadku wyniki są niemiarodajne z uwagi na zbyt krótki okres obserwacji (26 miesięcy).

O ile średnie indeksy sezonowości wydajności źródeł karpackich $(15,2 \%)$ i sudeckich $(15,0 \%)$ nie różnią się zasadniczo, to wypływy kotlin i Przedgórza Sudeckiego odznaczają się większą stabilnością wydatku niż źródła położone wyżej (ryc. 5A). Podobna relacja dotyczy wypływów Karpat i karpackich kotlin, lecz różnica w średniej porze koncentracji wydajności jest mniejsza. Natomiast pora koncentracji wydajności wyznaczona dla źródeł sudeckich wykazuje więcej podobieństw niż w przypadku wypływów karpackich (ryc. 5B). Wydaje się, że miara ta w mniejszym stopniu zależy od lokalizacji wypływów, w większym zaś od czynników ponadlokalnych, kształtujących 

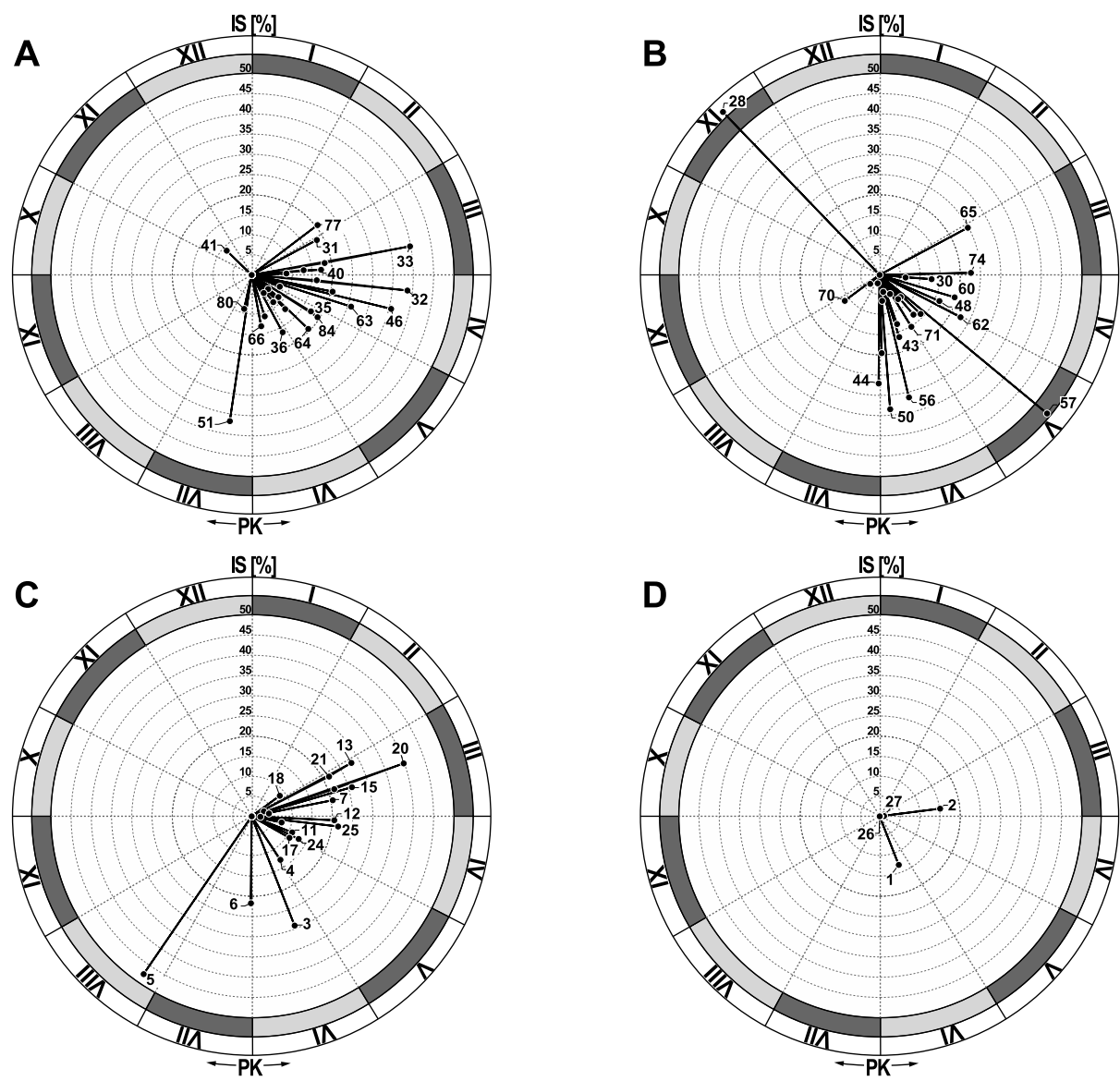

Ryc. 4. Graf interpretacyjny wskaźników sezonowości Markhama wydajności źródeł Sudetów i Karpat. Położenie punktów wskazuje na porę koncentracji wydajności w ciągu roku (PK), zaś długość wektorów obrazuje siłę sezonowości wyrażoną indeksem sezonowości (IS). Numery źródeł zgodne z tab.1 i ryc.1. A - Karpaty; B - karpackie zapadliska, obniżenia i pogórza; C - Sudety; D - sudeckie zapadliska, obniżenia i pogórza.

Fig. 4. Interpretation graph of the Markham's seasonality indices concerning spring discharge in the Sudetes and Carpathians. The location of points indicates the time of discharge concentration during the year (PK) and the vectors' length shows the seasonality power expressed by the seasonality index (IS). Numbers of springs are the same as in Fig. 1 and Table 1. A - Carpathian massifs; B - depressions, hollows and foothills of the Carpathians; C - Sudetian massifs; D - depressions, hollows and foothills of the Sudetes.

Źródto: opracowanie własne na podstawie dany PIG-PIB.

Source: author's own work on the basis of PIG-PIB data. 

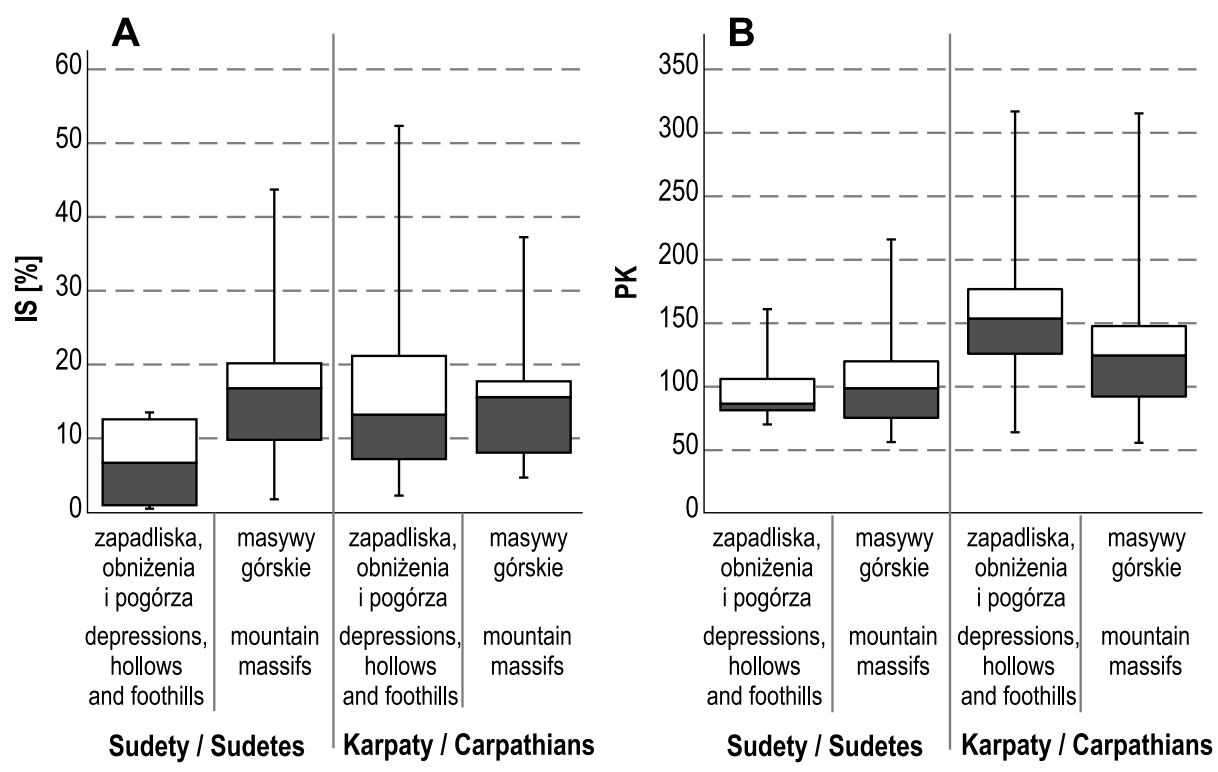

Ryc. 5. Charakterystyki rozkładów miar sezonowości Markhama wydajności źródeł Sudetów i Karpat: A - indeks sezonowości (IS) [\%]; B - pora koncentracji (PK) [nr dnia]

Fig. 5. Main distribution characteristics of spring discharge seasonality in the Sudetes and Carpathians: A - index of seasonality (IS) [\%]; B - date of concentration (PK) [day no.]

Objaśnienia: jak na ryc. 2.

Explanations: as in Fig. 2.

Źródto: opracowanie własne na podstawie danych PIG-PIB.

Source: author's own work on the basis of PIG-PIB data.

warunki klimatyczne w południowo-zachodniej Polsce. Koncentracja wydajności w źródłach sudeckich przypada przeciętnie o półtora miesiąca wcześniej (31 marca), niż w pozostałych źródłach karpackich (17 maja) - jeśli nawet pominąć wspomniane Wywierzysko Chochołowskie ( $\mathrm{nr} 41$ ). W niewielkim stopniu wynika to z różnic w przeciętnej wysokości wypływów - w Karpatach leżą one zaledwie średnio o $30 \mathrm{~m}$ wyżej niż w Sudetach. Wcześniejszą koncentrację wydajności źródeł sudeckich zapewniają wyraźne wpływy atlantyckie, przynoszące liczne odwilże śródzimowe, a wiosną - przyspieszające topnienie pokrywy śnieżnej i pojawienie się obfitszych opadów. Natomiast w Karpatach ponad połowa wypływów nieleżących w masywach górskich, reprezentuje stosunkowo wysoko położone Obniżenie Orawsko-Podhalańskie. Późna wiosna i wyższe sumy letnich opadów powodują, że pora koncentracji następuje tu przeciętnie o miesiąc później niż w paśmie Beskidów (ryc. 2), podobnie 
jak największą wydajność wypływów alpejskich notowano później niż źródeł Czech czy Polski (Moniewski 2015, 2016).

Sezonowość wydajności nie wydaje się natomiast zależna od rzędnej wypływu ani od jego wielkości. Oba wskaźniki sezonowości Markhama nie wykazują istotnego związku z wysokością ponad poziomem morza, jak również wielkość wydatku nie wpływa na indeks sezonowości. Jedyna istotna zależność łączy ilość wypływającej wody i porę koncentracji $(r=0,47)$. Jej kierunek wskazuje na to, że wydajność większych wypływów cechuje późniejsza pora koncentracji niż wydajność małych źródeł, charakteryzujących się mniejszą bezwładnością odpływu. Podobnymi właściwościami wyróżniają się źródła porowe - indeks sezonowości ich wydajności jest blisko trzykrotnie mniejszy aniżeli wypływów szczelinowych i krasowych, co potwierdza wcześniejsze obserwacje (Moniewski 2016). Natomiast koncentracja wydajności następuje o blisko 3 tygodnie później niż w przypadku wypływów szczelinowych, co także wynika z hydrogeologicznych właściwości źródeł.

\section{Podsumowanie i wnioski}

Wydajność źródeł Sudetów i Karpat cechuje znaczne zróżnicowanie sezonowe. Ilość wypływającej wody zależy nie tylko od zasilania atmosferycznego, lecz przede wszystkim od położenia warstwy wodonośnej, determinującej warunki retencjonowania i przepływu wody. Źródła szczelinowe, o zasilaniu określonym przez stopień uszczelinienia wodonośca, są zazwyczaj niewielkie i odznaczają się na ogół znacznie większą zmiennością wydatku niż wypływy krasowe czy porowe. Te ostatnie, z uwagi na powolną filtrację wody w ośrodku porowym, należą do najbardziej stabilnych pod względem wydajności. Natomiast zmienność wydajności dużych źródeł krasowych może być znacznie wyższa niż pozostałych typów wypływów. Wysokogórskie wywierzyska cechuje bowiem większa rozpiętość ekstremów wydajności, wynikająca z obfitości opadów letnich i niemal całkowitego braku zasilania zimą (Moniewski 2015; Pulido-Bosch i in. 1995).

Wypływy Sudetów charakteryzuje większa zmienność wydajności niż bardziej „kontynentalne” źródła Karpat. Duże źródła cechuje przy tym stabilność wypływu. Cechy kontynentalizmu klimatu wzrastają w kierunku wschodnim, powodując mimo podobnej sezonowości - wyraźnie późniejszą porę koncentracji wydajności. Warto przy tym zaznaczyć, że maksima wydajności dużych wypływów szczelinowych mogą być przesunięte w stosunku do opadów atmosferycznych nawet o kilka miesięcy (Michalczyk, Chabudziński 2013). Natomiast sezonowość wydajności w mniejszym stopniu zależy od wielkości wypływu, w większym zaś od jego zmienności - źródła stałe i mało zmienne charakteryzują się niższym indeksem sezonowości wydajności i późniejszą porą jej koncentracji. 


\section{Literatura}

Barczyk G., 2008, Wywierzyska tatræańskie. Krasowe systemy wywierzyskowe Tatr Polskich. TPN, Zakopane.

Bartnik A., 2007, Zró:nicowanie præestræenne wybranych cech fizykochemičnych wody źródet zlewni Bystrzycy Dusznickiej [w:] P. Jokiel, P. Moniewski, M. Ziułkiewicz (red.), Źródta Polski. Wybrane problemy krenologiczne, Regina Poloniae, Częstochowa, 181-191.

Buczyński S., Modelska M., Olichwer T., Tarka R., Staśko S., 2011, Charakterystyka krenologic:na masywów górskich Ziemi Kłodzkiej na podstawie bazy danych „Źródto”, Biuletyn PIG, 445, 17-26.

Buczyński S., Modelska M., Wcisło W., 2017, Wystepowanie i reżim źródet szczaw $i$ wód kwasoweglowych w zlewni górnej Muszynki, Przegląd Geologiczny, 65 (1), 23-31.

Buczyński S., Rzonca B., 2013, Źródta polsko-czeskiego pogranicæa w okolicach Zieleńca, Biuletyn PIG, 456, 45-50.

Chełmicki W. (red.), 2001, Źródta Wyżyny Krakowsko-Wieluńskiej i Miechowskiej. Zmiany w latach 1973-2000, IGiGP, UJ, Kraków.

Chełmicki W., Jokiel P., Michalczyk Z., Moniewski P., 2011, Distribution, discharge and regional characteristics of springs in Poland, Episodes, 34 (4), 244-256.

Czarnecka H., 1975, Reżim źródet na Wyżynie Matopolskiej, Prace IMGW, 6, Warszawa, 59-151.

Cieśliński R., Leśniowski P., 2013, Wyptywy wód podziemnych w województwie pomorskim, Gospodarka Wodna, 8, 306-311.

Dynowska I., 1986, Regionalne zróżnicowanie źródetw Polsce, Folia Geographica, Ser. Geogr.-Phys., 18, 5-30.

Fac-Beneda J., 2009, Hydrologic*ne i hydrochemic*ne cechy wody śródet na obs:arach mtodoglacjalnych [w:] R. Bogdanowicz, J. Fac-Beneda (red.), Zasoby i ochrona wód. Obieg wody i materii w zlewniach ræecะnych, Fundacja Rozwoju Uniwersytetu Gdańskiego, Gdańsk, 390-398.

Florek W., Pasamonik I., Szyca K., 2014, Chemizm wód źródta w Poddąbiu na tle cech środowiska i morfologii niszy \&́ódliskowej, Słupskie Prace Geograficzne, 11, 15-32.

Górniak A., Pietryczuk A., 2015, Źródta okolic Lęborka (pótnocna Polska), Gospodarka Wodna, $5,135-139$.

Humnicki W., 2006, Reżim \&́ódet pieninskich w świetle obserwacji limnimetrycznych, Pieniny Przyroda i Człowiek, 9, 29-39.

Humnicki W., 2012, Analiza recesji wydatku śódet pienińskich w swietle obserwacji limnimetrycznych, Pieniny - Przyroda i Człowiek, 12, 13-31.

Humnicki W., 2015, Zmiany wydajności monitorowanych źódet w Pienińskim Parku Narodowym w latach 2003-2014 (pieninski pas skatkowy), Przegląd Geologiczny, 63, 10/1, 750-755.

Jaworska-Szulc B., Pruszkowska-Caceres M., Przewłócka M., 2015, Zmiany wydajności wyptywów wód podziemnych mtodoglacjalnego obszaru morenowego na Pojezierzu Kaszubskim, Przegląd Geologiczny, 63, 10/1, 774-779. 
Jekatierynczuk-Rudczyk E., 2005, Transformacja składu chemicznego wody w strefie \&́ródlisk nizinnych [w:] J. Burchard (red.), Stan i antropogeniczne zmiany jakości wód w Polsce, t. III, Wyd. UŁ, Łódź, 259-268.

Jokiel P., 1994, Wieloletnie i sezonowe smiany wydajności wybranych \&ródet Polski, Wiadomości IMGW, 17 (4), 117-130.

Jokiel P., 1996, Wzorcowe krzywe wysychania i potencjaty zasobności kilkunastu \&ródet karpackich, Wiadomości IMGW, 19 (2), 67-77.

Jokiel P., 1997, Podstawowe cechy reżimu wydajności wybranych źródet karpackich, Acta Universitatis Lodziensis, Folia Geogr. Phys., 2, 27-43.

Kresic N., Stevanowic Z. (red.), 2010, Groundwater hydrology of springs: engineering, theory, management, and sustainability, Butterworth-Heinemann, Amsterdam, Boston.

Kř́̌̌ H., 1973, Processing of results of observations of spring discharge, Ground Water, 11 (5), 3-14, DOI: 10.1111/j.1745-6584.1973.tb02981.x.

Mazurek M., 2010, Hydrogeomorfologia obszarów źódliskowych (dorzecze Parsęty, Polska NW), Seria Geogr., 92, Wyd. Naukowe UAM, Poznań.

Małecka D., 1997, Źródta masywu tatræańskiego, Acta Universitatis Lodziensis, Folia Geogr. Phys., 2, 9-26.

Markham C. G., 1970, Seasonality of precipitation in The United States, Annals of the American Association of Geographers, 60 (3), 593-597, DOI: 10.1111/j.1467-8306.1970.tb00743.x.

Michalczyk Z., 1982, Charakterystyka hydrogeologicæna doræecza Łady. Z badań hydrogeologicznych w Polsce, t. 6. Biuletyn IG, 339, 109-161.

Michalczyk Z., 1983, Charakterystyka hydrologiczna źódta w Szczebrzeszynie, Annales UMCS, B, 35/36 (1), 193-207.

Michalczyk Z., 1993, Źródta zachodniej części Wyżyny Lubelskiej, Wyd. UMCS, Wydz. Biol. i Nauk o Ziemi, Lublin.

Michalczyk Z., Chabudziński Ł., 2013, Zmiany wydajności \&ródet w Wieræchowiskach w latach 1970-2012 (Roztocze Zachodnie), Biuletyn PIG, 456, Hydrogeologia, 14/2, 405-411.

Michalczyk Z., Chmiel S., Głowacki S., Zielińska B., 2009, Changes of springs' yield of Lublin Upland and Roztocze Region in 1998-2008, Journal of Water and Land Development, 12, 113-125, DOI: 10.2478/v10025-009-0009-6.

Michalczyk Z., Chmiel S., Głowacki S., Zielińska B., 2015, Monitoringowe badania źródet Wyżyny Lubelskiej i Roztocza, Przegląd Geologiczny, 63, 10/2, 935-939.

Michalczyk Z., Reder E., 1992, Charakterystyka hydrologiczna zródet okolic Zakrzówka, Annales UMCS, B, 44/45, 169-186.

Michalczyk Z., Turczyński M., 1999, Charakterystyka hydrologiczna śródetw Wqwolnicy na Wyżynie Lubelskiej, Annales UMCS, B, 54, 217-234.

Moniewski P., 2004, Źródła okolic Łodzi, Acta Universitatis Lodziensis, 87.

Moniewski P., 2015, Seasonal variability of discharge from selected springs in central Europe, Episodes, 38 (3), 189-196. 
Moniewski P., 2016, Zmienność wydajności wybranych \&ródet Polski i środkowej Europy w latach 2003-2014, Annales UMCS, B, 71 (1), 29-44, DOI: 10.17951/b.2016.71.1.29.

Nowakowski C., 1976, Charakterystyka źródet strefy czołowomorenowej Pojezierza Suwalskiego, Biuletyn Geologiczny, 21, Warszawa, 177-191.

Pius B., Kruszewska P., Glazik R., 2016, Wystepowanie wypływów wód podziemnych na obszarze Welskiego Parku Krajobrazowego, Studia Limnologica et Telmatologica, 10 (1), 13-21.

Puk K., 2005, Warunki występowania oraะ re:̇im wydajności i temperatury wypływów wód podziemnych w Sierakowskim Parku Krajobrazowym $i$ w obszarze przylegtym, Badania Fizjograficzne Nad Polską Zachodnią, Ser. Geogr. Fiz. 56, 137-156.

Pulido-Bosch A., Padilla A., Dimitrov D., Machkova M. 1995, The discharge variability of some karst spring in Bulgaria studied by time series analysis, Hydrological Sciences Journal, 40 (4), $517-532$.

Satora S., Bugajski P., Satora P., 2010, Zmienność reżimu wybranych źródetwystępujqcych w obrębie Beskidu Wyspowego i Gorców, Infrastruktura i Ekologia Terenów Wiejskich, 14, 195-206.

Siwek J., 2013, Wydajnośc zródet [w:] J. Siwek, M. Bascik (red.), Præyrodnicze i antropogeniczne przemiany źródet Wyżyn Krakowsko-Wieluńskiej i Miechowskiej oraz ich rola w krajobrazie naturalnym i kulturowym, IGiGP, UJ, Kraków, 43-58.

Szczucińska A.M., 2009, Wyptywy wód podziemnych w Rynnie Gryżyńsko-Grabińskiej, Wyd. Bogucki, Poznań.

Tomalski P., Tomaszewski E., 2015, 11. Metody, formuty $i$ wary oblicæeniowe aastosowane w pracy [w:] P. Jokiel (red.), Metody statystyczne w analiwach hydrologicznych środkowej Polski, Wyd. UŁ, Łódź, 215-271.

Wolanin A., Żelazny M., 2010, Sezonowe zmiany chemizmu wód śódet tatræańskich w slewniach Potoku Chochotowskiego i Potoku Kościeliskiego w 2009 roku [w:] T. Ciupa, R. Suligowski (red.), Woda w badaniach geografic:nych, UH-P, IG, Kielce, 347-355.

\author{
Adam Bartnik \\ Uniwersytet Łódzki \\ Pracownia Hydrologii i Gospodarki Wodnej \\ ul. Narutowicza 88, 90-139 Łód: \\ adam.bartnik@geo.uni.lod $\approx . p l$ \\ Piotr Moniewski \\ Centralne Laboratorium Badawce Gtównego Inspektoratu Ochrony Środowiska \\ w Warszawie Oddziat w Eodzi \\ ul. Lipowa 16, 90-743 Łód: \\ piotrmoniewski@gmail.com
}

